\title{
NELAYAN TIKU: TRADISI DAN KELEMBAGAAN SOSIAL BERDASARKAN BUDAYA MASYARAKAT LOKAL BERBASIS KOMUNITAS DALAM AKTIVITAS PENANGKAPAN IKAN
}

\author{
Lucky Zamzami ${ }^{1}$
}

\begin{abstract}
This article based on the results of research conducted at one of the villages the coastal areas of West Sumatra, in Nagari Tiku Selatan, Tanjung Mutiara District, Agam. This area have been based on traditions since ancestors held as tradition" "membangun rumpon", "festival Babantai and "Tolak Bala". The role of social institutions that have been rooted in self in Tiku fishermen whose presence is needed by the community. Social institutions set up in the form of "Arisan" association (JuloJulo), followed by wives of fishermen, Religious tradition (Yasinan), Social Death tradition, mutual assistance are bottom up. This institute aims to improve the socioeconomic members and provide a sense of security and safety in public life consistently carry out its consistent activities on a regular activities.
\end{abstract}

Keywords: Tiku Fishermen, Tradition, Social Institution, Role

\section{A. PENDAHULUAN \\ 1. Latar Belakang}

$\mathrm{K}$ alau berbicara mengenai suatu kesatuan sosial, masyarakat nelayan hidup, tumbuh, dan berkembang di wilayah pesisir atau wilayah pantai. Dalam konstruksi sosial masyarakat di kawasan pesisir, masyarakat nelayan merupakan bagian dari konstruksi sosial tersebut, meskipun disadari bahwa tidak semua desa-desa di kawasan pesisir memiliki penduduk yang bermatapencaharian sebagai nelayan. Walaupun demikian, di desa-desa pesisir yang sebagian besar penduduknya bermatapencaharian sebagai nelayan, petambak, atau pembudidaya perairan, kebudayaan nelayan berpengaruh besar terhadap terbentuknya identitas kebudayaan masyarakat pesisir secara keseluruhan (Ginkel, 2007; Kusnadi, 2010).

Konstruksi masyarakat nelayan mengacu kepada konteks bahwa suatu konstruksi masyarakat yang kehidupan sosial budayanya dipengaruhi secara signifikan oleh eksistensi kelompokkelompok sosial yang kelangsungan hidupnya bergantung pada usaha pemanfaatan sumber daya kelautan dan pesisir. Dengan memperhatikan struktur sumber daya ekonomi lingkungan yang menjadi basis kelangsungan hidup dan sebagai satuan sosial, masyarakat nelayan memiliki identitas kebudayaan yang berbeda dengan satuan-satuan sosial lainnya, seperti petani di dataran rendah, peladang di lahan kering dan dataran tinggi, kelompok masyarakat di sekitar hutan, dan satuan sosial lainnya yang hidup di daerah perkotaan.

Bagi masyarakat nelayan, kebudayaan merupakan sistem gagasan atau sistem kognitif yang berfungsi sebagai pedoman kehidupan, referensi pola-pola kelakuan sosial, serta sebagai sarana untuk menginterpretasi dan memaknai berbagai peristiwa yang terjadi di lingkungannya (Keesing, 1989:68-69; Kusnadi, 2010). Setiap gagasan dan praktik kebudayaan harus bersifat fungsional dalam kehidupan masyarakat. Jika tidak, kebudayaan itu akan hilang dalam waktu yang tidak lama. Kebudayaan haruslah membantu kemampuan survival masyarakat atau penyesuaian diri individu terhadap lingkungan kehidupannya. Sebagai suatu pedoman untuk bertindak bagi warga masyarakat, isi kebudayaan adalah rumusan dari tujuan-tujuan dan cara-cara yang digunakan untuk mencapai tujuan itu,

\footnotetext{
1 Penulis adalah Dosen tetap Jurusan Antropologi FISIP Universitas Andalas
} 
yang disepakati secara sosial (Kluckhon, 1984:85-91). Perspektif antropologis untuk memahami eksistensi masyarakat nelayan bertitik tolak dan berorientasi pada hasil hubungan dialektika antara manusia, lingkungan, dan kebudayaannya. Oleh karena itu, dalam beragam lingkungan yang melingkupi kehidupan manusia, satuan sosial yang terbentuk melalui proses demikian akan menmpilkan karakteristik budaya yang berbeda-beda. Orientasi hasil hubungan dialektika manusia tersebut menciptakan suatu tradisi yang dipengaruhi oleh kondisi religi keseharian nelayan dan peran kelembagaan sosial yang berdasarkan budaya lokal berbasis komunitas.

Tradisi bagi masyarakat nelayan dapat dilihat pada masyarakat Jawa dari segi kebudayaan upacara atau ritual adat yang merupakan wujud kegiatan religi atau kepercayaan, melalui tradisi Labuhan di desa Tegalsari Tegal Jawa Tengah (Widyatwati, 2012), tradisi Nadran di daerah pesisir Indramayu (Novita, 2013), tradisi ritual adat nelayan Larung Sesaji di pesisir kota Rembang (E-Journal- S1.undip.ac.id, 2013), tradisi ritual Petik Laut di Sendang Biru, Malang (Martin, dkk, 2011) dan tradisi

Tabuik di kota Pariaman (Tanjung, 2010). Sebagian besar tradisi sebagai wujud kegiatan religi selalu berkaitan erat dengan ritual sakral dengan tujuan untuk mendapatkan keselamatan dan berkah dari Allah agar dapat memperoleh hasil tangkapan ikan yang berlimpah, membersihkan lingkungan tempat tinggal dan lautan dari sesuatu yang dipandang tidak baik atau buruk serta jahat

Propinsi Sumatera Barat sebagai salah satu propinsi yang berada di pesisir Barat pulau Sumatera yang memiliki potensi penangkapan dan pengelolaan ikan di laut yang sangat besar sepanjang $375 \mathrm{~km}$, tidak terlepas dari adanya hasil hubungan dialektika masyarakat nelayan yang telah menciptakan tradisi- tradisi yang merupakan wujud kegiatan religi atau kepercayaan melalui peran kelembagaan sosial yang berdasarkan budaya lokal berbasis komunitas pada nelayan tersebut.

Salah satu daerah yang menjadi sentral nelayan dan usaha kelautan di Sumatra Barat selain daripada Kabupaten Pesisir Selatan, Kota Padang, Kabupaten Padang Pariaman dan Kabupaten Pasaman Barat adalah Kabupaten Agam, tepatnya di
Kecamatan Tanjung Mutiara. Kecamatan Tanjung Mutiara merupakan satu dari 16 kecamatan di Kabupaten Agam yang memiliki panjang pantai sekitar $43 \mathrm{~km}, 27$ $\mathrm{km}$ per segi terumbu karang dan 65 hektare hutan Manggrov. Jumlah Nelayan di kecamatan Tanjung Mutiara tercatat sekitar 1.952 orang dan aktif sekitar 1.750 orang dengan produksi ikan mencapai 3.415 ton/tahun dengan hasil tangkap jenis pelagis, udang dan teri (http://www.sumbarprov.go.id/index.php).

Masyarakat nelayan di daerah ini terpusat di nagari Tiku Selatan dan nagari Tiku V Jorong. Kedua nagari tersebut merupakan kawasan pemukiman nelayan yang memiliki konstruksi masyarakat nelayan dalam konteks bahwa masyarakatnya sangat dipengaruhi secara signifikan oleh eksistensi kelompokkelompok sosial yang menciptakan tradisitradisi sebagai perwujudan kegiatan religi melalui peran kelembagaan sosial yang dibentuk berdasarkan budaya lokal masyarakat tersebut.

Kelompok-kelompok nelayan yang ada di nagari Tiku Selatan saat ini berjumlah 21 kelompok nelayan. Dari 21 kelompok nelayan tersebut, diantaranya 13 kelompok yang berasal dari perikanan tangkap, sedangkan untuk 8 kelompok perikanan budidaya. Pada tahun 2012, kelompok-kelompok nelayan tersebut telah mendapatkan bantuan dana Pengembangan Usaha Mina Pedesaan (PUMP) perikanan tangkap dan budidaya dari Dinas Kelautan dan Perikanan Provinsi Sumatera Barat. Bantuan dana Pengembangan Usaha Mina Pedesaan (PUMP) ini bertujuan untuk mendorong program peningkatan produksi dan pemberdayaan masyarakat pembudidayaan ikan dan nelayan dalam rangka meningkatkan pendapatan, kesejahteraan dan dapat merubah pola hidup nelayan menjadi lebih baik (Korantransaksi, 2012).

Dalam rangka mengatasi masalah yang dihadapi nelayan tersebut, maka sejak tahun 2001-2008, pemerintah telah mencanangkan suatu program yang diupayakan dapat langsung menyentuh kepentingan masyarakat nelayan, terutama nelayan tradisional yang berorientasi kepada pertumbuhan ekonomi. Di samping bertujuan untuk meningkatkan kesejahteraan masyarakat nelayan, juga bertujuan untuk mendidik agar nelayan lebih 
mandiri dan mempunyai kemampuan untuk hidup lebih baik dalam memanfaatkan sumber daya yang ada secara optimal dan berkelanjutan. Melalui program pemerintah melalui program pemberdayaan ekonomi masyarakat pesisir (PEMP) ${ }^{5}$, tetap memperhatikan nilai budaya (tradisi) dan wujud religi melalui peran kelembagaan yang tumbuh dan berkembang dalam masyarakat lokal, sehingga program yang ada tersebut diharapkan dapat meningkatkan partisipasi masyarakat dalam pengambilan keputusan dan pengawasan pengelolaan sumber daya laut dan daerah pesisir (Departemen Kelautan dan Perikanan, 2001: 6-7; Zamzami, 2010:114).

Selama proses pelaksanaan program pemberdayaan masyarakat tersebut, masyarakat yang berbasis komunitas lokal telah mengembangkan kelembagaan dari aspek kelembagaan secara sosial dan ekonomi yang berisi nilainilai tradisional dan kearifan lokal sehingga setiap program pemerintah yang masuk ke wilayahnya dapat ditampung melalui kelembagaan yang telah terbentuk tersebut ${ }^{6}$. Keberadaan kelembagaan sosial ekonomi dalam masyarakat nelayan mampu mewujudkan rasa saling tolong menolong dan toleransi diantara kelompokkelompok nelayan yang setiap tahunnya terbentuk dengan sendirinya. Lembaga dalam suatu komunitas masyarakat pesisir terdiri dari organisasi pada tingkat nelayan serta kelembagaan masyarakat desa yang diartikan sebagai "norma lama" atau aturan -aturan sosial yang telah berkembang secara tradisional dan terbangun atas budaya lokal sebagai komponen dan pedoman pada beberapa jenis/tingkatan lembaga sosial yang saling berinteraksi dalam memenuhi kebutuhan pokok masyarakat untuk mempertahankan nilai. Norma lama yang dimaksud yaitu aturan- aturan sosial yang merupakan bagian dari lembaga sosial dan simbolisasi yang mengatur kepentingan masyarakat di masa lalu (Sallatang, 1982; Arief, 1999).

$$
\text { Selain adanya program }
$$

pemberdayaan yang dilaksanakan oleh pemerintah, salah satu sarana untuk memberikan perlindungan pada masyarakat nelayan adalah membekali mereka dengan pengetahuan akan arti penting hidup berkelompok Pada masyarakat nelayan, pola hidup berkelompok sebenarnya sudah lama dikenal, namun aktivitas mereka belum banyak yang mengarah pada pengangkatan sosial ekonomi mereka. Menyadari akan hal tersebut, pemerintah melaksanakan berbagai kegiatan yaitu pengelolaan yang berbasis masyarakat. Pengelolaan yang berbasis pada masyarakat oleh pemerintah sebenarnya sudah pernah dilakukan. Namun pengelolaan itu, lebih banyak berdimensi politik daripada sosial, ekonomi, dan budaya lokal dikarenakan sifat pengelolaannya bersifat top-down. Sebagai contoh; pembentukan LMD (BPD), LKMD, Karang Taruna, Dasa Wisma, Pos Yandu dan lainnya. Lembaga-lembaga ini sebagian kurang berfungsi dalam melaksanakan tugasnya, dan mereka tidak lebih hanya sekedar penghias nama di Kantor-kantor desa.

\section{Permasalahan}

$\mathrm{N}$ elayan Tiku merupakan salah satu komunitas nelayan di Kabupaten Agam yang kondisi realitasnya sampai saat ini mengelola, memelihara dan memanfaatkan sumberdaya hayati laut berdasarkan norma dan nilai budaya melalui tradisi dan religi yang bersifat partisipatif, assosiatif, analogik dan orientif yang melembaga serta dipertahankan melalui pengendalian sosial (social control) oleh setiap warganya.

Norma dan nilai budaya tersebut merupakan pengetahuan yang lahir secara turun temurun dimiliki oleh nelayan Tiku untuk memanfaatkan sumber daya perikanan, telah melahirkan perilaku sebagai hasil dari adaptasi mereka terhadap lingkungannya yang mempunyai implikasi positif terhadap kelestarian lingkungan laut. Meskipun norma dan nilai budaya melalui tradisi dan religi tidak seluruhnya dapat terwarisi oleh generasi penerusnya, namun nilai- nilai yang masih ada dapat dijadikan modal dalam pemanfaatan sumber daya perikanan secara berkelanjutan.

Norma dan nilai budaya yang telah melembaga mampu diperankan oleh eksistensi kelompok- kelompok sosial yang ada dalam masyarakat nelayan sehingga membentuk kelembagaan sosial atas dasar budaya lokal setempat. Peran kelembagaan sosial nelayan terbentuk dari 
perilaku yang terus menerus hidup dalam komunitas nelayan, dan mengalami proses penyesuaian dengan adanya kendalakendala yang dihadapi serta potensi lingkungannya. Kelembagaan yang ada pada komunitas masyarakat nelayan dimaksudkan sebagai suatu sistem organisasi yang berlaku dan diakui oleh komunitas nelayan, baik yang termasuk kelembagaan formal maupun informal (Astuty, 2006:115). Seperti halnya kelembagaan ekonomi dalam masyarakat nelayan terbentuk oleh adanya proses yang saling mempengaruhi antara lingkungan tempat hidup masyarakat dengan masyarakat itu sendiri (nelayan), dan peranan lembaga ini sangat berpengaruh terhadap berlangsungnya kegiatan ekonomi masyarakat nelayan diantaranya adalah nelayan tangkap (Astuty, 2006:116).

Kelembagaan sosial bukan saja ditemukan pada masyarakat petani akan tetapi juga pada masyarakat nelayan telah lama dikenal. Kelembagaan sosial merupakan sistem informal yang eksis di masyarakat nelayan dan terbentuk dari tradisi yang telah ada di masyarakat nelayan. Peran kelembagaan sosial membantu pola bagi hasil yang muncul akibat dari ketidakpastian hasil tangkapan yang cenderung sangat berfluktuasi sehingga bisa membantu kecukupan ekonomi mereka (Masyhuri, 2000).

Berdasarkan latar belakang tersebut diatas, maka rumusan permasalahan dalam penelitian ini akan melihat sebagai berikut:

1. Bagaimana perwujudan hubungan nilai tradisi dan peran kelembagaan sosial atas dasar budaya lokal masyarakat dalam aktivitas penangkapan ikan pada nelayan Tiku?

2. Bagaimana nilai tradisi sebagai wujud kepercayaan dan peran kelembagaan sosial dalam aktivitas penangkapan ikan yang masih tetap dipertahankan dalam konteks kekinian pada nelayan Tiku?

\section{B. Tinjauan Pustaka \\ i. Kebudayaan Masyarakat Nelayan} anusia dalam kehidupannya dituntut melakukan suatu usaha untuk mendatangkan hasil dalam pemenuhan kebutuhan hidupnya. Usaha yang dilakukan dapat berupa tindakantindakan untuk memperoleh dan memanfaatkan sumber-sumber daya yang memiliki nilai ekonomis guna memenuhi syarat-syarat minimal atau kebutuhan dasar agar dapat bertahan hidup, dimana kebutuhan dasar merupakan kebutuhan biologis dan lingkungan sosial budaya yang harus dipenuhi bagi kesinambungan hidup individu dan masyarakat (Imran, 1989).

Kebudayaan adalah keseluruhan pengetahuan manusia sebagai mahluk sosial yang digunakan untuk memahami dan menginterpretasikan lingkungan dan pengalamannya serta menjadi kerangka landasan bagi terwujudnya kelakuan. Kebudayaan juga dilihat sebagai seperangkat mekanisme- mekanisme kontrol, yaitu rencana-rencana, resep-resep, aturan-aturan, instruksi-instruksi untuk mengatur tingkah laku (Geertz, 1992) Dalam kehidupan masyarakat nelayan, kebudayaan umum lokal setempat sangat mempengaruhi aktivitas mereka dalam meningkatkan kesejahteraan ekonomi masyarakat nelayan.

Dilihat dari prespektif antropologis, masyarakat nelayan berbeda dari masyarakat lain, seperti masyarakat petani, perkotaan atau masyarakat di dataran tinggi. Prespektif antropologis ini didasarkan pada realitas sosial bahwa masyarakat nelayan memiliki pola-pola kebudayaan yang berbeda dari masyarakat lain sebagai hasil dari interaksi mereka dengan lingkungan beserta sumber daya yang ada didalamnya. Pola-pola kebudayaan itu menjdai kerangka berpikir atau referensi perilaku masyarakat nelayan dalam menjalani kehidupan sehari-hari (Kusnadi, 2005). Dilihat, dimensi pekerjaan, masyarakat nelayan terdiri atas 2 kelompok, yaitu: kelompok yang terkait (langsung) dan yang tidak terkait dengan aktifitas kelautan/perikanan. Kelompok yang terkait (langsung) dengan aktifitas kelautan/perikanan terdiri dari 2 sub kelompok, yaitu: sub kelompok pencari/ penangkap hasil kelautan/perikanan dan pembudidaya hasil kelautan/perikanan. Sedangkan pencari hasil kelautan /perikanan meliputi pemilik alat produksi/tangkap seperti toke, juragan, bos, atau nama lain. Mereka pun beragam, bisa berada pada lapisan atas, menengah atau bawah. Kemudian juga masuk di dalamnya nelayan pekerja (buruh), 
nelayan mandiri, dan pedagang ikan (kecil, menengah, dan besar).Selanjutnya pembudidaya hasil kelautan/perikanan mencakup pemilik alat produksi, pekerja (buruh), nelayan pembudidaya mandiri, dan pedagang hasil budidaya kelautan/perikanan (kecil, menengah, dan besar).

Kelompok yang tidak terkait (langsung) dengan aktifitas kelautan /perikanan seperti pedagang/pemilik warung makanan, pedagang kebutuhan sehari-hari, petugas koperasi, dan sebagainya. Dilihat dari dimensi sosial budaya, masyarakat nelayan dapat dibedakan antara: satu, kelompok yang melihat sumber daya kelautan/perikanan tidak terbatas, kapan saja selagi musim baik bisa dieksploitasi, dan tidak memiliki pe-rencanaan. Dua, kelompok yang melihat sumber daya kelautan/perikanan terbatas, namun untuk jenis tertentu sumber daya dapat dibudidayakan, dan memiliki perencanaan (Damsar dan Nia Elfina, 2005). Masyarakat nelayan memiliki kebudayaan yang unik yang berbeda dengan masyarakat lainnya, namun sebagian besar nelayan yang tergolong miskin merupakan nelayan artisanal yang memiliki keterbatasan kapasitas penangkapan baik penguasaan teknologi, metode penangkapan, maupun permodalan. Masalah kemiskinan juga disebabkan adanya ketimpangan pemanfaatan sumber daya ikan. Di satu sisi, ada daerah yang padat tangkap dengan jumlah nelayan besar terutama di Pantura Jawa. Di sisi lain ada daerah yang masih potential namun jumlah nelayannya sedikit seperti di Papua, Maluku,NTT dan Ternate. Masalah struktural yang dihadapi nelayan makin ditambah dengan persoalan kultural seperti gaya hidup yang tidak produktif dan tidak efisien.

Secara alami ada interaksi yang sangat kuat antara ketersediaan sumber daya ikan, jumlah, perilaku, dan kapasitas nelayan serta ekonomi dari hasil usaha penangkapan. Oleh karena itu, kemiskinan nelayan harus dipandang sebagai suatu sistem yang memiliki komponen saling berinteraksi. Dengan demikian pendekatan yang paling tepat dalam penanggulangan kemiskinan adalah dengan pendekatan kesisteman (Mubyarto, 1984).

Dalam konteks studi nelayan di wilayah Tiku, Kabupaten Agam, terdapat beberapa penelitian yang telah dilaksanakan oleh peneliti dalam komunitas tersebut. Studi nelayan Tiku mengenai kehidupan sosial ekonomi tahun 1970-2009 dilihat dari perspektif sejarah (Sarjulis, 2011), studi mengenai Dampak pemberian kredit koperasi bagi nelayan (Yulinda, dkk, 2011). Disamping itu, studi mengenai perencanaan pembangunan berbasis perikanan tangkap (Milasari, 2004) dan studi mengenai bagi hasil penangkapan ikan pada nelayan Tiku (Yolanda, 2013). Jika ditelusuri, studi penelitian mengenai nilai-nilai budaya dan religi melalui peran kelembagaan sosial dalam aktivitas penangkapan ikan masih kurang dalam nelayan Tiku, sehingga penelitian ini layak untuk dilaksanakan.

\section{ii. Tradisi secara Konseptual}

$\mathrm{T}$ radisi adalah sebuah kata yang sangat akrab terdengar dan terdapat di segala bidang. Tradisi menurut etimologi adalah kata yang mengacu pada adat atau kebiasaan yang turun temurun, atau peraturan yang dijalankan masyarakat. Secara langsung, bila adat atau tradisi disandingkan dengan stuktur masyarakat melahirkan makna kata kolot, kuno, murni tanpa pengaruh, atau sesuatu yang dipenuhi dengan sifat takliq. Tradisi merupakan sinonim dari kata "budaya" yang keduanya merupakan hasil karya. Tradisi adalah hasil karya masyarakat, begitupun dengan budaya. Keduanya saling mempengaruhi. Tradisi menurut terminologi, seperti yang dinyatakan oleh Siti Nur Aryani dalam karyanya, Oposisi Pasca Tradisi, tercantum bahwa tradisi merupakan produk sosial dan hasil dari pertarungan sosial politik yang keberadaannya terkait dengan manusia. Atau dapat dikatakan pula bahwa tradisi adalah segala sesuatu yang turun temurun, yang terjadi atas interaksi antara klan yang satu dengan klan yang lain yang kemudian membuat kebiasaan-kebiasaan satu sama lain yang terdapat dalam klan itu kemudian berbaur menjadi satu kebiasaan. Dan apabila interaksi yang terjadi semakin meluas maka

Tradisi merupakan segala sesuatu yang berupa adat, kepercayaan dan 
kebiasaan. Kemudian adat, kepercayaan dan kebiasaan itu menjadi ajaran-ajaran atau paham-paham yang turun temurun dari para pendahulu kepada generasigenerasi paska mereka berdasarkan dari mitos-mitos yang tercipta atas manifestasi kebiasaan yang menjadi rutinitas yang selalu dilakukan oleh klan-klan yang tergabung dalam suatu bangsa. Secara pasti, tradisi lahir bersama dengan kemunculan manusia dimuka bumi. Tradisi berevolusi menjadi budaya. Itulah sebab sehingga keduanya merupakan personifikasi. Budaya adalah cara hidup yang dipatuhi oleh anggota masyarakat atas dasar kesepakatan bersama. Kedua kata ini merupakan keseluruhan gagasan dan karya manusia, dalam perwujudan ide, nilai, norma, dan hukum, sehingga keduanya merupakan

(http://dewasastra.wordpress.com/

2012/04/04/tradisi-bahasa-dan-istilah).

\section{iii. Pengertian Kelembagaan}

$\mathrm{K}$ elembagaan merupakan suatu sistem yang sengaja dibuat manusia untuk mengatur cara, aturan, proses dan peran masing-masing komponen pendukung di dalamnya untuk mencapai tujuan tertentu. Komponen pendukung di dalam suatu kelembagaan antara lain subjek atau orang sebagai penggerak sistem, segala aturan dan cara yang mengatur jalannya suatu sistem di dalam kelembagaan yang melibatkan banyak peran subjek tersebut.

Pengertian kelembagaan secara sosiologis, yaitu kelembagaan ibarat organorgan dalam tubuh manusia yang menjalankan masyarakat tersebut. Setiap fungsi dalam masyarakat pasti dijalankan oleh sebuah (atau lebih) kelembagaan. Untuk kebutuhan hidup, dalam hal berproduksi dan distribusi, dijalankan oleh kelembagaan ekonomi. Setiap orang yang terlibat di dalamnya diikat oleh suatu pola nilai dan norma sebagai pedoman bersikap dan berperilaku, yang dimantapkan kemudian dengan adanya struktur baku. Struktur merupakan visualisasi dari siapa orang yang terlibat dan posisionalnya.

Menurut Soekanto (2002), istilah kelembagaan diartikan sebagai lembaga kemasyarakatan yang mengandung pengertian abstrak perihal adanya normanorma dan peraturan-peraturan tertentu yang menjadi ciri lembaga tersebut. Sedangkan menurut Tjondronegoro dalam Pranadji (2003), pengertian tentang lembaga cenderung menyempitkan makna lembaga dengan pendekatan ciri kemajuan masyarakat. Soelaeman (1974) menuliskan bahwa kelembagaan dapat bertindak sesuai dengan kehendak masyarakat yang berperan besar terhadap sirkulasi kelembagaan tersebut. Sedikit berbeda dengan Rahardjo yang dikutip oleh Pasaribu (2007), konsep kelembagaan yang dianut oleh masyarakat menggunakan konsep lembaga sosial yang secara lebih sederhana diartikan sebagai kompleks norma-norma atau kebiasaan- kebiasaan untuk mempertahankan nilai-nilai yang dipandang sangat penting dalam masyarakat.

Berdasarkan beberapa pendapat tentang pengertian kelembagaan, dapat disimpulkan bahwa kelembagaan merupakan suatu sistem yang syarat dengan nilai dan norma yang bertujuan mengatur kehidupan manusia di dalam kelembagaan pada khususnya maupun manusia di luar kelembagaan pada umumnya.Norma-norma yang tumbuh dalam masyarakat memiliki tingkatan kekuatan mengikat tersendiri. Seperti yang dipaparkan Soekanto (2002) dalam Sosiologi sebagai Pengantar bahwa untuk dapat membedakan kekuatan mengikat norma-norma tersebut dikenal adanya empat pengertian, yaitu:

a. Cara (usage)

b. Kebiasaan (folksway)

Setiap tingkatan di atas memiliki kekuatan memaksa yang semakin besar mempengaruhi perilaku seseorang untuk menaati norma. Begitu pula yang dipaparkan oleh Soemardjan Soelaeman (1974) bahwa setiap tingkatan tersebut menunjukkan pada kekuatan yang lebih besar yang digunakan oleh masyarakat untuk memaksa para anggotanya mentaati norma-norma yang terkandung didalamnya.

Kelembagaan adalah sekumpu lan jaringan dari relasi sosial yang melibatkan orang-orang tertentu, memiliki tujuan tertentu, memiliki aturan dan norma, serta memiliki struktur. Kelembagaan dapat berbentuk sebuah relasi sosial yang melembaga (non formal institution), atau dapat berupa lembaga dengan struktur dan badan hukum (formal 
institution). Suatu relasi sosial dapat disebut sebagai sebuah kelembagaan apabila memiliki empat komponen, yaitu adanya: (1) Komponen aturan/kebijakan. Setiap kelembagaan mengembangkan seperangkat kesepakatan yang dipegang secara bersama, sehingga peran masingmasing yang terlibat dalamlembaga tersebut dapat kelihatan; (2) Komponen person (SDM). Orang-orang yangterlibat di dalam satu kelembagaan dapat diidentifikasi dengan jelas; (3) Komponen kepentingan (koordinasi). Orang-orang tersebut pasti sedang diikat oleh satu kepentingan atau tujuan, sehingga di antara mereka harus saling berinteraksi; dan, Komponen struktur/institusi dan tata laksana. Setiap orang memiliki posisi dan peran,yang harus dijalankannya secara benar. Orang tidak bisa merubah-rubah posisinyad engan kemauan sendiri.

\section{iv. Pendekatan Berbasis Komunitas}

$\mathrm{H}$ awe mendefinisikan komunitas sebagai kumpulan orang, dengan tiga alasan pengelompokan, yaitu secara geografis, secara demografis, dan secara lembaga (entitas) sosial. Kita dapat menyebut kumpulan orang dalam satu wilayah rukun tetangga adalah komunitas (secara geografis). Dalam bidang pembangunan, setiap pekerjaan yang dilakukan di tingkat komunitas kemudian disebut berbasis komunitas (community based), dengan maksud membedakannya dengan pekerjaan di belakang meja dan advokasi kebijakan pemerintah. Dalam arti sempit, community-based sering dimaknai "service delivery" atau penyediaan layanan untuk komunitas. Soal apakah dilakukan oleh masyarakat (community-managed) atau pihak luar, selama kegiatan itu berlangsung di akar rumput, tetap banyak disebut berbasis komunitas (Nugroho dan Yon, 2011).

Visi tentang komunitas berbedabeda, karenanya, definisi tentang komunitas sangat beragam, berkarakter jamak dan tidak homogen. Philip Alperson menulis ulang pengertian awal tentang "komunitas organik dengan hierarki alamiah yang berasosiasi feodal dan kuno, bersifat hierarki, dengan basis stratifikasi sosial seperti jender, kasta, kelas yang dikonstruksikan 'alamiah' dan sudah diatur "dari atas".Komunitas bisa merupakan suatu kumpulan dan tatanan yang disebut sebagai "paguyuban" dengan suatu nilai "kekerabatan" seperti kesetiakawanan, komitmen, imbal balik, dan kepercayaan (Koentjaraningrat, 1987) atau juga kategori deskriptif atau seperangkat variabel: tempat, minat, keterikatan, atau kemanunggalan (Frazer, 1999) Variabel-variabel ini dapat bersifat simbolik sebagai sumber daya dan tempat penyimpanan dari makna-makna dan acuan untuk identitas mereka (Cohen,1985).

Anggota-anggota suatu komunitas mempunyai suatu kesamaan seperti kesamaan wilayah, satuan hukum, karakteristik lahiriah, atau bahasa. Kesamaan itu secara signifikan membedakan mereka dari anggota komunitas yang lain. Ada suatu garis bersifat maya yang membatasi suatu komunitas dari komunitas lainnya. Normanorma atau adat apa sajakah yang ikut terlibat di dalamnya? Ada tiga norma dasar, yaitu toleransi (rasa keterbukaan terhadap sesama anggota komunitas, rasa hormat, dan kemauan untuk mendengarkan dan belajar satu sama lain); timbal balik (rasa kesediaan untuk menolong, altruisme tanpa pamrih-kalaupun ada mungkin berjangka panjang); dan kepercayaan (bahwa orang dan lembaga dalam komunitas akan berperilaku secara konsisten, jujur, dan patut).

Pendekatan berbasis komunitas dilaksanakan oleh dan bersama dengan komunitas di mana mereka berperan kunci dalam perencanaan, desain, penyelenggaraan, pengawasan, dan evaluasi. Disepakati bahwa dalam pendekatan ini komunitas adalah pelaku utama yang membuat dan melaksanakan keputusan-keputusan penting sehubungan dengan pengelolaan sumber daya perikanan tersebut.

\section{Tujuan Dan Manfaat Penelitian}

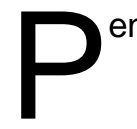

enelitian ini bertujuan sebagai berikut: 1. Untuk menjelaskan perwujudan hubungan nilai tradisi dan peran kelembagaan sosial atas dasar budaya lokal masyarakat dalam aktivitas penangkapan ikan pada nelayan Tiku.

2. Untuk menganalisis nilai tradisi 
sebagai wujud kepercayaan dan peran kelembagaan sosial dalam aktivitas penangkapan ikan yang masih tetap dipertahankan dalam konteks kekinian pada nelayan Tiku

Melalui penelitian ini diharapkan dapat:

1. Hasil penelitian sangat penting dilakukan sehingga menambah kepada bahan-bahan kajian ilmu Sosial, khususnya bidang kajian Antropologi Maritim.

2. Mengembangkan penguatan kelembagaan dalam komunitas nelayan melalui analisis nilai budaya dan perwujudan religi sehingga upaya percepatan pembangunan secara sosial di wilayah pesisir Kabupaten Agam dapat tercapai.

3. Memecahkan masalah kelembagaan yang telah ada dalam komunitas nelayan, dari aspek sosial dan ekonomi melalui kultur masyarakat lokal berbasis komunitas pesisir khususnya nelayan.

4. Melalui hasil kajian ini, diharapkan dapat menemukan model pengembangan kelembagaan berdasarkan kultur masyarakat lokal berbasis komunitas, dalam rangka mendukung penanggulangan kemiskinan yang menjadi salah satu isu nasional.

\section{Metode Penelitian}

L okasi yang dijadikan wilayah penelitian adalah di Nagari Tiku Selatan, Kecamatan TanjungMutiara, Kabupaten Agam. Lokasi ini dipilih karena berada di wilayah pesisir pantai Barat Sumatera yang memiliki lebih dari 1.750 orang nelayan yang aktif dalam aktivitas perikanan dan kelautan. Dengan jumlah nelayan yang cukup besar tersebut terbentuklah 21 kelompok nelayan yang tersebar di nagari tersebut. Dalam kurun waktu 2 tahun terakhir, berbagai bantuan dari pihak pemerintah daerah Sumatera Barat melalui Dinas Kelautan dan Perikanan Provinsi Sumatera Barat datang ke kelompok-kelompok nelayan tersebut dalam bentuk bantuan dana
Pengembangan Usaha Mina Pedesaan (PUMP) yang bertujuan untuk mendorong program peningkatan produksi dan pemberdayaan masyarakat pembudidayaan ikan dan nelayan dalam rangka meningkatkan pendapatan, kesejahteraan dan dapat merubah pola hidup nelayan menjadi lebih baik.

Dengan bantuan yang diperoleh, dibuktikan bahwa dalam masyarakat nelayan di lokasi penelitian ini memiliki nilai budaya tradisi dan perwujudan religi melalui peran kelembagaan yang berdasarkan budaya masyarakat lokal yang cukup kuat, walaupun dalam perkembangannya kelembagaan tersebut terkesan sebagai alat kelengkapan proyek, belum sebagai wadah untuk pemberdayaan masyarakat secara hakiki. Akibatnya, eksistensi dan kinerjanya kurang mengembirakan, bahkan keberadaannya tidak berkesinambungan. Hal ini terlihat beberapa kelompok nelayan yang ada saat ini hanya sebatas terdaftar secara administrasi, namun keberadaan dan aktivitasnya hampir tidak ada, kalaupun ada masih sangat terbatas. Oleh karena itu, kegagalan pembangunan pada sektor kelautan dan perikanan yang umumnya banyak dijumpai di tiap daerah pesisir karena belum siapnya lembaga di tingkat komunitas nelayan dalam menjalankan fungsinya tersebut.

Dalam penelitian ini menggunakan pendekatan penelitian kualitatif. Penelitian kualitatif memusatkan perhatian pada prinsip-prinsip umum yang mendasari perwujudan satuan-satuan gejala yang ada dalam kehidupan sosial. Dalam penelitian kualitatif yang dianalisis bukan variabelvariabel tetapi yang dianalisis dalam kaitan hubungan dengan prinsip-prinsip umum dari satuan-satuan gejala lainnya dengan menggunakan budaya masyarakat yang diteliti dan dari hasil analisis tersebut dianalisis lagi dengan menggunakan seperangkat teori yang berlaku (Neuman, 2006:149; Rudito, 2008: 78).

Dalam penelitian kualitatif yang menjadi sasaran kajian adalah kehidupan sosial atau masyarakat sebagai satu kesatuan atau sebuah kesatuan yang menyeluruh. Karena itu, penelitian kualitatif juga biasanya dikaitkan dengan pengertian yang sama dengan pendekatan yang dikenal dalam antropologi yang dinamakan 
pendekatan holistik. Dalam penelitian kualitatif tidak dikenal sampel tetapi penelitian kasus yang ditelitinya secara mendalam dan menyeluruh untuk memperoleh gambaran mengenai prinsipprinsip umum atau pola-pola yang berlaku umum berkenaan dengan gejalagejala yang ada dalam kehidupan sosial (Rudito, 2008:79).

Penelitian ini berbentuk studi kasus yang mengutamakan penelitian yang menyelidiki fenomena dan konteksnya saling terkait dan memanfaatkan banyak bukti atau informasi untuk mencari data. Dalam penelitian studi kasus, keutuhan dari objek perlu dipertahankan.

Teknik pengumpulan data yang telah dilakukan adalah menggunakan teknik observasi partisipasi, wawancara bebas dan mendalam dan studi kepustakaan. Pemilihan informan diambil secara purposive (sengaja), dimana pengambilan informan yang bersifat tidak acak dan juga berdasarkan pertimbanganpertimbangan tertentu yang dapat memberikan informasi sesuai dengan masalah yang diteliti. Saat penelitian berlangsung, pemilihan informan dibagi ke dalam dua, yaitu informan kunci dan informan biasa. Menurut Bungin bahwa penentuan siapa yang harus menjadi informan kunci melalui beberapa pertimbangan di antaranya: orang yang bersangkutan memiliki pengalaman pribadi sesuai dengan permasalahan yang diteliti, usia orang yang bersangkutan telah dewasa, orang yang bersangkutan sehat jasmani dan rohani, bersifat netral dan memiliki pengetahuan yang luas mengenai permasalahan yang diteliti (Bungin, 2004:56).

Informan kunci yang telah dipilih adalah nelayan yang tergabung dalam kelompok-kelompok nelayan yang memiliki partisipasi yang aktif dalam aktivitas penangkapan ikan. Sedangkan informan biasa adalah pejabat pemerintahan kecamatan dan nagari dan tokoh-tokoh masyarakat. Berikut ini informan yang berhasil diwawancarai dalam penelitian.

Data-data yang telah dikumpulkan oleh peneliti termasuk juga catatan lapangan dikelompokkan oleh peneliti atas dasar aktivitas khusus yang ada dan diteliti. Kemudian dari pengelompokkan data tersebut, data-data itu kemudian diabstraksikan dan dikaitkan satu dengan lainnya sebagai satu kesatuan kejadian dan fakta yang terintegrasi. Dari abstraksi tersebut maka akan tampak pranata sosial yang berlaku di wilayah atau komuniti tersebut (Bungin, 2004:60).

Dalam menganalisis tentunya selalu terkait dengan konsep yang telah dipelajari sebelumnya. Sehingga dari hasil analisis akan tampak kesesuaian dari data yang diperolehnya dengan konsep yang dipelajarinya atau akan berbeda dengan konsep yang dipelajarinya karena masalah sosial akan selalu berbeda antara satu masyarakat dengan masyarakat lainnya.

Setelah itu disusun sesuai dengan kategori-kategori dan kemudian disimpulkan. Apabila dalam kesimpulan masih menimbulkan keraguan maka dilakukan pengkategorian ulang hingga seluruh data yang telah berhasil dikumpulkan dianggap sesuai dengan tujuan penelitian. Temuan di lapangan akan diolah dengan data yang didapat dari literatur dan akan disajikan dalam suatu karya etnografi deskriptif.

\section{E. Hasil Dan Pembahasan \\ 1.1 Gambaran Umum Nagari Tiku Selatan, Kecamatan Tanjung Mutiara, Kabupaten Agam}

$\mathrm{N}$ agari Tiku Selatan terletak di Kecamatan Tanjung Mutiara, Kabupaten Agam, Sumatera Barat. Nagari Tiku Selatan terdiri dari 7 jorong ${ }^{8}$, yang terdiri: (1) Jorong Gasan Kaciak dengan luas wilayah $1.141 \mathrm{Ha}$; (2) Jorong Banda Gadang dengan luas wilayah 724 $\mathrm{Ha}$; (3) Jorong Pasa Tiku dengan luas wilayah $111 \mathrm{Ha}$; (4) Jorong Pasia Tiku dengan luas wilayah $100 \mathrm{Ha}$; (5) Jorong Kampung Darek dengan luas wilayah $520 \mathrm{Ha}$; (6) Jorong Pasia Paneh dengan luas wilayah $605 \mathrm{Ha}$; dan (7) Jorong Sungai Nibuang dengan luas wilayah 385 $\mathrm{Ha}$.

Jumlah jorong yang berada di daerah pesisir sebanyak 4 buah (21\%) dan jorong bukan pesisir sebanyak 15 buah (79\%), dengan jumlah penduduk pesisir dengan mata pencaharian sebagai nelayan sebanyak 2.152 KK (2\%). Nagari Tiku Selatan berbatasan sebelah utara dengan Nagari Tiku V Jorong, sebelah Selatan dengan Nagari Batang Gasan, sebelah Barat berbatasan dengan Samudra Indonesia dan sebelah Timur berbatasan 
dengan Nagari Tiku Utara.

Nagari Tiku Selatan memiliki ketinggian tempat berkisar $2 \mathrm{~m}$ dari permukaan laut dengan suhu rata-rata sekitar $26^{0} \mathrm{C}-30^{\circ} \mathrm{C}$ dengan rata-rata curah hujan $2000 \mathrm{~mm}$. Wilayah ini terdiri dari dataran rendah, dengan tinggi pesisir pantai yang rendah. Berdasarkan penggunaan lahan dan luas wilayah menjelaskan bahwa penggunaan lahan perumahan dan lahan persawahan yang memiliki aliran irigasi mendominasi luas wilayah di Nagari Tiku Selatan, Kecamatan Tiku Selatan, Kabupaten Agam. Nagari Tiku Selatan memiliki garis pantai yang cukup panjang dan juga memiliki keindahan dari aspek pemandangan lautnya.

\subsection{Sejarah Nagari}

$\mathrm{P}$ ada abad 18an, Tiku adalah salah satu tempat pelabuhan besar di daerah Minangkabau. Salahsatu bukti sejarah disana adalah gaya pakaian "marapulai", dimana gaya berpakaian marapulai sama seperti yang di pakai para matador di spanyol. Kaos kaki tinggi dan rompi merupakan salah satu bukti sejarah bahwa ketika Portugis meninggalkan Tiku. Kata Tiku sendiri berasal dari Tako atau Teko, artinya tempat penampungan. Ini artinya bahwa Tiku di jadikan sebagai tempat logistik para penjajah. (http://nanangsarfinal.blogspot.com/2008/09/ sisa-sejarah-tiku.html diakses tanggal 17 Oktober 2013).

Kabupaten Agam mempunyai sejarah yang panjang dan komplit, baik di bidang Pemerintahan maupun di bidang adat istiadat. Diawali dari Kerajaan Minangkabau pada pertengahan abad ke17, dimana rakyat Minangkabau telah memanggul senjata untuk berontak melawan penjajahan Belanda. Pemerintahan Minangkabau yang disebut Ranah Minang, dimana Kabupaten Agam tempo dulu, selain Sumatera Barat juga termasuk daerah Limo Koto Kampar (Bangkinang) yang sekarang termasuk Propinsi Riau, Daerah Kabupaten Kerinci (Sungai Penuh) sekarang termasuk Propinsi Jambi dan sebagian daerah Tapanuli Selatan (Koto Napan) yang sekarang secara administrasi berada di Propinsi Sumatera Utara. Pemerintahan adat mencakup Luhak dan Rantau, dimana Pemerintahan Wilayah Luhak terdiri dari Luhak Tanah Datar, Luhak Limo Puluah dan Luhak Agam. Komisariat Pemerintahan Republik Indonesia di Sumatera yang berkedudukan di Bukittinggi mengeluarkan peraturan tentang pembentukan daerah Otonom Kabupaten di Sumatera Tengah yang terdiri dari 11 Kabupaten yang salah satunya Kabupaten Singgalang Pasaman dengan ibukotanya Bukittinggi yang meliputi kewedanan Agam Tuo, Padang Panjang, Maninjau, Lubuk Sikaping dan Kewedanaan Talu ( kecuali Nagari Tiku, Sasak dan Katiagan).

Dengan Surat Keputusan Gubernur Militer Sumatera Tengah No. 171 tahun 1949, daerah Kabupaten Agam diperkecil dimana Kewedanaan Talu dimasukkan ke daerah Kabupaten Pasaman, sedangkan beberapa nagari di sekitar Kota Bukittinggi dialihkan ke dalam lingkungan administrasi Kotamadya Bukittinggi. Keputusan Gubernur Militer Sumatera Tengah tersebut dikukuhkan dengan Undang-undang No. 12 tahun 1956 tentang pembentukan Daerah Tingkat II dalam lingkungan Propinsi Sumatera Tengah, sehingga daerah ini menjadi Daerah Tingkat II Kabupaten Agam. Pada tanggal 19 Juli 1993 secara de facto, ibukota Kabupaten Agam telah berada di Lubuk Basung yang dikuatkan dengan dikeluarkannya Peraturan Pemerintah Republik Indonesia (PP Nomor 8 Tahun 1998) (http://agammedia.blogspot.com/2011/09/sejarah-dansosiologi.html diakses tanggal 17 Oktober 2013).

Menurut silsilah (ranji), kaum keturunan Datuk Rangkayo Basa (DRB) di Kanagarian Tiku berasal dari sebuah perkampungan kaum suku Jambak bernama Galo Gandang di Tanah Data. Salah seorang dari kaum ini, pada masa yang tidak teridentifikasi, merantau ke pesisir barat bernama Puti Sanang Hati dengan membawa empat orang anaknya, tiga perempuan dan seorang laki-laki. Anak yang pertama bernama Puti Ambat, yang kedua bernama Puti Langgam, yang ketiga adalah laki-laki yang bernama Sutan Mara Basa, serta yang bungsu bernama Puti Manis. Menurut ranji yang saat ini masih disimpan oleh kaum keluarga DRB di Galo 
Gandang Tanah Data, Puti Sanang Hati mempunyai empat orang anak, namun nama anak-anak tersebut tidak disebutkan karena ranji mereka putus sampai Puti Sanang Hati saja, namun hanya tertera bahwa Puti Sanang Hati memiliki empat orang anak, satu diantaranya adalah lakilaki.

Dalam dalam ranji keluarga DRB di Tiku, nama-nama kaum keluarga ini tercatat dengan baik. Sehingga singkatnya untuk menjaga tali hubungan darah ini tidak putus, maka pada masa itu DRB pun dilewakan di nagari rantau pesisir ini. Sutan Mara Basa sebagai satu-satu anak lelaki dalam kaum ini dilewakan gelar Datuk Rangkayo Basa. Karena ciri-ciri dari Sutan Mara Basa ini orangnya tinggi berdada cekung, maka beliau juga disebut oleh orang sebagai Datuk Rangkayo Basa nan Cakuang Dado (Di samping tersebutkan pada ranji, tanda kebenaran kaum keturunan ini berasal dari kaum keluarga Jambak Galo Gandang Tanah Data dapat dilihat pada pandam pekuburan kaum Jambak di Jawi-jawi Tiku yang batu nisannya berasal dari kerajinan Galo Gandang Tanah Data. Menurut kisah yang siriwayatkan oleh para tuo-tuo kaum suku jambak, Sutan Mara Basa bergelar datuk Rangkayo Basa (nan cakuang dado) terkenal karena berbagai keistimewaan yang dimilikinya sehingga hal ini membuatnya sangat disegani di dalam dan di luar nagari Tiku.

Sehingga selain gelar Datuk Rangkayo Basa merupakan gelar sako kaum jambak juga merupakan gelar pemimpin dalam kanagarian Tiku yang menaungi suku-suku lainnya di kanagarian Tiku. Hal ini terlihat dari kepemimpinanpemimpin penyandang gelar sako DRB di Tiku yang semuanya merupakan wali nagari kanagarian Tiku. Ranji DRB di kanagarian Tiku (pesisir barat) yang asli dibuat dalam tulisan arab, sama halnya dengan ranji yang asli yang ada di tangan kaum kelurga DRB di Galo Gandang Tanah Data. Kemudian oleh salah seorang cucu kemenakan St Mara Basa Datuk Rangkayo Basa yang bernama Haji Abdul Wahab atau Buyuang Enek (bergelar Sutan Badar Alam), ranji bertulisan arab ini dibuatkan ke dalam bahasa latin (Indonesia), sementara ranji yang asli bertulisan arab tersebut masih disimpan dengan baik.

Dalam sistem kekerabatan matriakhat di Minangkabau, sako dan pusako diwariskan secara turun temurun menurut garis ibu. Kawasan pusako kaum keluarga suku Jambak ini meliputi daerah Jawi-jawi sampai ke Cacang (Tiku). Demikian pula halnya, ketika Sutan Mara Basa bergelar Datuk Rangkayo Basa memasuki masa purna tugas sebagai pemegang sako tinggi kaum keluarga suku Jambak, maka sako ini pun diteruskan oleh kemenakan dan cucu-cucu kemenakannya yang semuanya juga menjadi pimpinan di kanagarian Tiku. Dalam ranji kaum ini dapat ditemui nama-nama cucu kemenakan yang meneruskan sako kaum ini. Cuku kemenakan yang terakhir memegang gelar sako Datuk Rangkayo Basa ini bernama Sutan Tamin, juga wali nagari Tiku. Namun ketika Sutan Tamin Datuk Rangkayo Basa wafat sekitar tahun 1970, gelar sako ini tidak dapat terselenggarakan lagi dengan baik karena kemenakan yang seharusnya melanjutkan kepemimpinan kaum keluarga, diantaranya $\mathrm{H}$ Abdul Wahab bergelar Sutan Badar Alam, berada diperantauan.

Namun agar tanda pusako dan identitas kaum Jambak kanagarian Tiku keturunan kaum keluarga Datuk Rangkayo Basa tidak hilang, semasa hidupnya Sutan Badar Alam telah memugar pandam pakuburan kaum Jambak yang terletak di Simpang Tiga Jawi-jawi Tiku dan bangunan rumah gadang yang teletak di Jawi-jawi (tidak jauh dari pandam pakuburan ini) direhabilitasi dan sebagian tanahnya dijadikan bagunan sebuah mesjid yang bernama Nurul Wahab. Pada pandam pakuburan kaum ini terbaringlah Puti Sanang Hati dan anakanaknya termasuk Sutan Marah Basa Datuk Rangkayo Basa serta semua generasi kaum suku Jambak kanagarian Tiku kaum keturunan Datuk Rangkayo Basa yang berasal dari Galo Gandang Tanah Data ini.

Sako Datuk Rangkayo Basa sudah tidak dilewakan lagi semenjak meninggal Sutan Tamin sebagai pewaris yang terakhir, walau ada upaya dari berbagai pihak untuk meminjamnya. Di samping itu, berbagai perkembangan situasi politik telah menyebabkan pula berbagai hal terjadi pada gelar sako DRB ini. Datuk Rangkayo Basa boleh 
tiada, namun semangat dalam membangun kampung dan kaum keluarga seperti yang pernah dilakukan oleh pemangku-pemangku sako Datuk Rangkayo Basa masih melekat di dalam jiwa setiap anggota kaum keluarga, baik yang masih berada di kampung maupun yang di perantauan (http://pusakampa.blogspot.com/2009/06/su ku-jambak-sejarah-ringkas.html diakses tanggal 17 Oktober 2013).

\subsection{Keadaan Demografi}

$\mathrm{B}$ erdasarkan data kependudukan Nagari Tiku Selatan tahun 2012, jumlah penduduk sebanyak 13.003 jiwa orang, dengan penduduk laki-laki berjumlah 6.699 jiwa dan penduduk perempuan 6.304 jiwa orang. Jumlah kepala keluarga (KK) adalah 2.608.

Berdasarkan hasil wawancara diperoleh bahwa jumlah penduduk terbanyak di Nagari Tiku Selatan yang dikategorikan pada usia produktif berada pada tingkat umur antara 20 tahun hingga 50 tahun. Hal tersebut terkait erat dengan berbagai pekerjaan yang ditekuni oleh masyarakat di Nagari Tiku Selatan.

\subsection{Mata Pencaharian}

$\mathrm{D}$ alam pemenuhan kebutuhan hidup masyarakat di Nagari Tiku Selatan, baik kebutuhan dasar seperti kebutuhan sandang, pangan dan papan maupun kebutuhan sekunder seperti kebutuhan pendukung lainnya sangat diperlukan mata pencaharian untuk mencapai usaha tersebut. Dalam pemenuhan kebutuhan tersebut, di dalam masyarakat mempunyai mata pencaharian yang beragam/bervariasi. Demikian juga dengan masyarakat Nagari Tiku Selatan yang memiliki beragam mata pencaharian.

Bahwa sebagian besar penduduk di Nagari Tiku Selatan bermata pencaharian sebagai petani, buruh dan nelayan, terutama nelayan buruh sebanyak 145 $(11 \%)$. Salah satu penyebabnya adalah kondisi wilayah Nagari Tiku Selatan yang terletak memanjang di garis pantai daerah Nagari Tiku Selatan.

\subsection{Tingkat Pendidikan}

$\mathrm{P}$ endidikan merupakan kebutuhan utama masyarakat di Nagari Tiku Selatan sebagai usaha untukmenambah ilmu pengetahuan mereka dan juga mengangkat pada derajat yang lebih tinggi. Kesadaran masyarakat di Nagari Tiku Selatan terhadap pentingnya pendidikan cukup tinggi dimana sebagian besar masyarakatnya sudah mengenyam pendidikan padan tingkat SMP dan SMA. Meskipun demikian, sebagian masyarakatnya juga ada yang menamatkan pendidikan hanya pada tingkat SD.

Bahwa tingkat pendidikan di Nagari Tiku Selatan sudah cukup tinggi. Hal tersebut diperlihatkan melalui jumlah penduduk yang telah menamatkan pendidikan SD, SMP, SMA dan perguruan tinggi sebanyak 6.350 (90\%). Meskipun demikian, diperoleh juga terdapat penduduk yang tidak menamatkan pendidikan SD $(10 \%)$. Pada umumnya, mereka yang tidak menamatkan pendidikan SD dikarenakan faktor ekonomi dan kesempatan.

Untuk menunjang aktivitas pendidikan masyarakat di Nagari Tiku Selatan sangat dibutuhkan sarana dan prasarana agar tujuan pendidikan dapat tercapai. Jumlah sarana pendidikan di Nagari Tiku Selatan cukup memadai dengan tersedianya sarana pendidikan SMP dan SMA. Hal tersebut diperlihatkan dari tingkat pendidikan yang cukup tinggi dengan tingkat pendidikan SMP dan SMA.

\subsection{Pola Pemukiman Nagari Tiku Selatan}

$\mathrm{P}$ ola pemukiman adalah wujud dari bentuk pemukiman pada suatu daerah yang meliputi pola letak tempat tinggan dan bentuk rumah di pemukiman tersebut. Pola letak pemukiman di Nagari Tiku Selatan tidak berbeda jauh dengan pola pemukiman wilayah pesisir di daerah lain, dimana rumah-rumah membentang sepanjang pantai di pesisir pantai Tiku.

Pola pemukiman Nagari Tiku Selatan yang mengikuti garis pantai dimulai dari Jorong Gasan Kaciak , kemudian dilanjutkan menuju Jorong Banda Gadang, Jorong Pasa Tiku dan Jorong Pasia Tiku. Untuk 3 jorong lainnya berada di sepanjang 
perbukitan yang berada di seberang garis pantai. Untuk menuju Nagari Tiku Selatan, dapat ditempuh dengan kendaraan beroda dua dan empat dengan sarana jalan yang cukup baik sehingga dapat ditempuh selama 1.5 jam perjalanan dari ibu kota Sumatera Barat, yaitu kota Padang.

Kepemilikan rumah yang berada di sekitar pantai adalah sebagian besar dimiliki oleh rumah tangga nelayan buruh dan juga pedagang ikan berskala kecil. Pada umumnya, bentuk rumah di Nagari Tiku Selatan, terutama kampung-kampung di sekitar pantai terdiri dari rumah tidak permanen dan semi permanen dan hanya beberapa rumah saja yang permanen, yaitu sekitar 5-10 rumah. Untuk rumah-rumah yang berada di sekitar jalan utama yang menghubungkan antar jorong di Nagari Tiku Selatan, keadaannya lebih baik dari rumah yang ada di dekat pantai. Biasanya rumahrumah di wilayah ini dihuni oleh pedagang ikan dengan skala yang lebih besar dibandingkan dengan pedagang yang ada di pinggir pantai.

Berdasarkan observasi (melalui pengamatan), terdapat beberapa rumah di pemukiman sekitar wilayah pantai (5-10 rumah) yang dihuni oleh para nelayan yang tidak layak untuk menjadi tempat tinggal. Rumah mereka hanya beralaskan pasir pantai dan berdindingkan kayu dan juga atapnya terbuat dari seng yang sudah berkarat dan berlubang.

Di sekitar pemukiman nelayan, terdapat 2-4 warung makanan yang selalu dipenuhi oleh para nelayan buruh, terutama sekali ketika mereka sudah selesai melaksanakan aktivitas penangkapan ikan seperti memukat dan juga pada saat terjadinya badai (cuaca tidak baik). Aktivitas yang biasa mereka lakukan adalah berdiskusi tentang aktivitas penangkapan ikan, bermain domino/kartu dan hanya sekedar minum kopi.

\subsection{Aktivitas Sosial Budaya Masyarakat}

$\mathrm{M}$ asyarakat nagari Tiku Selatan menganut sistem kekerabatan matrilineal, yakni kekerabatan mengacu kepada garis keturunan perempuan. Tradisi sosial yang paling unik di nagari ini adalah tradisi perkawinan dan kematian. Tradisi perkawinan adalah perempuan 'membeli' laki-laki, artinya perempuan yang membayar biaya dan mahar perkawinan. Dalam tradisi ini ada konsep uang 'hilang' dan uang 'menjemput'. Uang hilang adalah uang yang digunakan untuk mengganti pengeluaran orangtuanya dalam membesarkan anak laki-lakinya baik berupa uang atau barang seperti motor atau mobil. Penggantian uang hilang ini tergantung kepada tingkat pendidikan dan pekerjaan laki-laki tersebut, apabila tinggi pendidikannya maka semakin tinggi uang hilangnya. Untuk uang menjemput adalah uang yang dibayar ketika menjemput lakilaki saat pelaksanaan pernikahan, dengan uang menjemput berupa ringgit sebanyak 12 emas. Dalam tradisi perkawinan ini didalamnya terdapat prosesi seperti adat menurunkan pengantin perempuan dari rumah ibunya (bundo kanduang), adanya upacara mencukur rambut, 'balatui badia', adat menjemput pengantin laki-laki (bagalombang duo baleh).

Selain tradisi perkawinan, tradisi kematian di wilayah ini terbilang unik. Tradisi kematian disebut dengan istilah 'batagak adat' dengan cara 'Bejamba', yaitu masing-masing keluarga, tetangga dan kerabat dalam satu suku yang melayat membawa makanan yang kemudian ditumpuk-tumpuk menjadi sebuah gunung makanan hingga mencapai lebih kurang 2 meter. Setelah makanan menggunung, maka dilaksanakan acara berdoa (zikir) bersama, setelah itu dilakukan kegiatan membagi-bagi harta warisan, "malewang gala", upacara doa setelah 3, 7, 14, 40 dan 100 hari kematian anggota keluarga.

\subsection{Aktivitas Ekonomi Perikanan Masyarakat}

ktivitas ekonomi perikanan yang
dilakukan oleh nelayan pada
umumnya berkelompok tetapi ada juga yang melakukannya secara perorangan. Kegiatan tersebut sebagian besar dilakukan oleh pihak laki-laki yang berumur diatas 15 tahun. Pendapatan nelayan di nagari Tiku Selatan berkisar antara Rp.25.000,- hingga Rp. 100.000,-. Pendapatan nelayan termasuk rendah dikarenakan sebagian besar nelayan di nagari Tiku Selatan tersebut adalah nelayan buruh (60\%). Aktivitas penangkapan ikan pada masyarakat nelayan Nagari Tiku Selatan, yaitu aktivitas membagan, memayang, 
memukat dan menjaring. Teknologi pada penangkapan ikan menjaring menggunakan peralatan jaring dan perahu. Jaring yang selalu dipergunakan oleh masyarakat nelayan Nagari Tiku Selatan adalah yang berukuran 100-200 m. Jaring ini ada yang jahitannya halus dan kasar. Jaring yang halus ukuran matanya memiliki panjang 25$20 \mathrm{~cm}$ dan lebarnya kira-kira $5 \mathrm{~cm}$, sedangkan jaring yang jahitannya kasar ukuran matanya memiliki panjang 50-60 cm dan lebar $10 \mathrm{~cm}$. Untuk jahitan yang kasar adalah untuk menangkap ikan yang besarbesar seperti ikan gembolo, ikan gurigak, belatuk dan soaso, sedangkan jahitan yang halus atau rapat adalah untuk menangkap ikan yang kecil-kecil seperti ikan campu, pinang-pinang, maco dan tete. Untuk menangkap ikan dengan menjaring mempergunakan sebuah perahu yang panjangnya lebih kurang $4 \mathrm{~m}$ dan lebarnya 1 $\mathrm{m}$. Perahu yang banyak digunakan oleh masyarakat nelayan Nagari Tiku Selatan saat ini sudah banyak memakai mesin perahu/mesin tempel.

Hasil tangkapan ikan yang diperoleh langsung di bawa ke pasar tradisional Tiku Selatan dan disana sudah ada agen atau pembeli yang menanti. Biasanya agen-agen tersebut telah ditentukan oleh induk semang. Alasan lain nelayan menjual ikan di pasar tradisional Tiku Selatan karena semua jenis ikan dapat diterima baik besar maupun kecil, begitu juga dengan jenis-jenisnya.

Nagari Tiku Selatan merupakan Nagari yang memiliki potensi sumber daya alam yang cukup banyak dilihat dari berbagai aspek seperti Nagari Tiku Selatan mempunyai wilayah laut yang dengan garis pantai sepanjang $\pm 6 \mathrm{~km}$ dan disertai dengan Tempat Pendaratan Ikan (TPI) beserta fasilitas penunjang lainnya. Potensi hasil laut nagari Tiku Selatan telah menjadi salah satu andalan ekonomi yang utama dari nagari Tiku Selatan.

Dari segi infrastruktur dan perhubungan Nagari Tiku Selatan dilalui oleh jalan negara yang menghubungkan Ibukota Propinsi dan lbukota Kabupaten. Ditambah dengan beradanya ibukota Kecamatan Tanjung Mutiara di Nagari Tiku Selatan, maka hampir seluruh kantor instansi pemerintah dan swasta serta sekolah-sekolah berada di Nagari Tiku Selatan. Dari Segi Ekonomi otomatis dengan keberadaan TPI dan pasar serikat maka seluruh aktifitas utama perikanan dan ekonomi berada di Nagari Tiku Selatan . Ditambah dengan keberadaan kantor beberapa Bank BPR dan bank umum, Koppem serta BMT yang terletak di Nagari Tiku Selatan yang sangat membantu pertumbuhan ekonomi masyarakat. Dari segi sumber daya manusia Nagari Tiku Selatan mempunyai asset SDM yang cukup banyak dengan tingkat pendidikan yang cukup tinggi serta mempunyai beragam keahlian. Namun potensi tersebut belum tergali dan dimanfaatkan secara maksimal.

\subsection{Adat, Budaya dan Agama di Nagari Tiku Selatan}

dat merupakan suatu tatanan
kehidupan yang telah terjadi pada
masa-masa yang lalu untuk mengatur kehidupan yang berEtika, Sopan dan berAdab sesuai dengan tuntunan ajaran Agama Islam.Sebagai falsafah Minang Kabau Adat Basandi Syarak, Syarak Basandi Kitabullah yang bermakna Menjunjung nilai- nilai Agama yang Implementasinya tertuang dalam Adat Istiadat di Nagari. Dan Adat Istiadat mempunyai peran penting dalam kehidupan bermasyarakat dan bernagari, disamping menjaga nilai-nilai Luhur Adat dan Budaya peran Adat dalam penyelenggaraan Pemerintahan sangat menentukan, dengan Tali Tigo Sapilin dan Tungku Tigo Sajarangan. Dengan jalannya peran Adat di semua unsur yang ada di masyarakat seperti Niniak Mamak, Cadiak Pandai, Alim Ulama, Bundo Kanduang Pemuda yang keterlibatan unsure tersebut terhadap memperlancar proses pembangunan di Nagari. Untuk mengembalikan tegaknya nilai-nilai Adat Istiadat yang berlaku di Nagari Tiku Selatan perlu dilakukan upaya Pelestarian, Pemahaman, Pengamalan nilai-nilai Adat Istiadat ditengah-tengah masyarakat seperti yang sudah di jalankan dan di laksanakan dalam Nagari:

$$
\text { Seiring dengan Kebijakan }
$$

Pemerintah Propinsi Sumatera Barat "babaliak Kanagari" dengan Otonomi Daerah. Babaliak ka Nagari merupakan artian dari kembali kepada tradisi yang telah lama mulai memudar, namun seiring arus globalisasi kemajuan zaman saat ini, secara keseluruhan penerapannya belum 
mampu diterjemahkan secara konkrit ditengah-tengah kehidupan masyarakat, sehingga muncul kekhawatiran akan makin luntur dan rendahnya pemahaman agama bagi generasi muda. Sebagai langkah untuk mengantisipasi hal ini, telah dilakukan berbagai langkah dan upaya oleh Tokoh-tokoh pemangku kepentingan masyarakat di Nagari Tiku Selatan untuk meramaikan Mesjid, Mushalla dan melakukan kegiatan-kegiatan keagamaan dengan penyediaan Sarana dan Prasarana ibadah lainnya untuk pecapaian Nagari yang Baldatun Thaibathun Warabbun Ghafur.

\subsection{Pranata Sosial dalam Masyarakat Nelayan}

$\mathrm{M}$ enurut Koentjaraningrat (1964), lembaga kemasyarakatan/lembaga sosial atau pranata sosial adalah suatu sistim norma khusus yang menata suatu rangkaian tindakan berpola mantap guna memenuhi suatu kebutuhan khusus dari manusia dalam kehidupan masyarakat. Kesimpulan dari definisi di atas adalah adanya sistem norma, sistem norma yang mengatur tindakan berpola dan tindakan berpola itu untuk memenuhi kehidupan manusia dalam kehidupan masyarakat.

Rahardjo (1999) menyatakan bahwa kelembagaan sosial (social institution) secara ringkas dapat diartikan sebagai kompleks norma-norma atau kebiasaan-kebiasaan untuk mempertahankan nilai-nilai yang dipandang sangat penting dalam masyarakat, merupakan wadah dan perwujudan yang lebih konkret dari kultur dan struktur. Berdasarkan pada beberapa pengertian tadi, dapat dipahami bahwa kelembagaan sosial dalam masyarakat nelayan adalah "norma atau kebiasaan yang terstruktur dan terpola serta dipraktekkan terus menerus untuk memenuhi kebutuhan anggota masyarakat yang terkait erat dengan penghidupan dari bidang perikanan di wilayah pantai".

Kelembagaan perikanan pada masyarakat pesisir pantai yang masih bersahaja terkait erat dengan kegiatan ekonomi masyarakat tradisional. Pada masyarakat desa yang kegiatan ekonominya masih belum didominasi sistim ekonomi uang, menyebabkan masih kuatnya kait-mengkait antara kegiatan ekonomi dan sosial, sistem gotong royong dalam proses produksi perikanan, sistem bagi hasil, sistem hutang, dan sistim tradisional lainnya yang terkait dengan operasi produksi perikanan.

Lembaga sosial dan ekonomi lahir ditujukan untuk memenuhi kebutuhan masyarakat terhadap kehidupannnya. Kebutuhan masyarakat meskipun tidak linier cenderung merupakan kebutuhan yang lahir dari kebutuhan individu sebagai anggotanya. Tradisi gotong royong secara nyata telah melembaga secara sosial dan mengakar kuat, ini diwujudkan dalam berbagai aktivitas keseharian masyarakat nelayan di Nagari Tiku Selatan. Secara umum aktivitas gotong royong memiliki tema sentral sebagai mutual help antar anggota masyarakat yang mana masingmasing pihak terlibat saling memberikan kontribusi dan sebagai reward-nya mereka mendapatkan gain dari aktivitas yang dikerjasamakan Semangat timbal balik-reciprocity melekat kuat sebagai penunjuk bahwa proses kerjasama berlangsung dengan fair. Aktivitas gotong royong dalam berbagai dimensinya memberikan implikasi semangat dan value untuk saling memberikan jaminan/selfguarantying atas hak dan kelangsungan hidup antar sesama warga masyarakat yang masih melekat cukup kuat di pedesaan.

Kelembagaan sosial dalam masyarakat nelayan adalah norma atau kebiasaan yang terstruktur dan terpola serta dipraktekkan terus menerus untuk memenuhi kebutuhan anggota masyarakat yang terkait erat dengan penghidupan dari bidang perikanan di wilayah pesisir pantai. Dalam kehidupan komunitas nelayan, posisi dan fungsi kelembagaan sosial nelayan merupakan bagian pranata sosial yang memfasilitasi interaksi sosial atau social interplay dalam suatu komunitas. Kelembagaan sosial nelayan juga memiliki titik strategis (entry point) dalam menggerakkan sistem perikanan di wilayah pesisir pantai. Untuk itu segala sumberdaya yang ada di pesisir pantai perlu diarahkan/diprioritaskan dalam rangka peningkatan profesionalisme dan posisi tawar nelayan (kelompok sosial nelayan). Saat ini potret nelayan dan kelembagaan sosial nelayan diakui masih belum sebagaimana yang diharapkan. 
Kelembagaan sosial nelayan umumnya berjalan dengan baik. Hal tersebut disebabkan kelompok nelayan pada umumnya dibentuk berdasarkan kepentingan teknis untuk memudahkan pengkoordinasian apabila ada kegiatan atau program pemerintah, sehingga lebih bersifat orientasi program, dan menjamin kemandirian kelompok dan keberlanjutan kelompok. Partisipasi dan kekompakan anggota kelompok dalam kegiatan kelompok masih relatif baik, ini tercermin dari tingkat kehadiran anggota dalam pertemuan kelompok cukup tinggi. Pengelolaan kegiatan produktif anggota bersifat kelompok. Kelompok sebagai forum kegiatan bersama mampu menjadi wadah pemersatu kegiatan anggota dan pengikat kebutuhan anggota secara bersama, sehingga kegiatan produktif individu lebih menonjol. Kegiatan atau usaha produktif anggota kelompok selalu dihadapkan pada masalah kesulitan permodalan, ketidakstabilan harga dan jalur pemasaran yang terbatas. Pembentukan dan pengembangan kelembagaan menggunakan basis social capital setempat dengan prinsip kemandirian lokal, yang dicapai melalui prinsip keotonomian dan pemberdayaan.

Pembentukan dan pengembangan kelembagaan berdasarkan konsep cetak biru (blue print approach) yang seragam. Introduksi kelembagaan dari luar memperhatikan struktur dan jaringan kelembagaan lokal yang telah ada, serta kekhasan ekonomi, sosial, dan politik yang berjalan. Pembentukan dan pengembangan kelembagaan berdasarkan pendekatan yang bottom up, menyebabkan tumbuhnya partisipasi masyarakat. Kelembagaan-kelembagaan yang dibangun untuk memperkuat ikatan horizontal, bukan ikatan vertikal. Anggota suatu kelembagaan terdiri atas orangorang dengan jenis aktivitas yang sama. Tujuannya agar terjalin kerjasama yang pada tahap selanjutnya diharapkan daya tawar mereka meningkat. Untuk ikatan vertikal diserahkan kepada mekanisme pasar, dimana otoritas pemerintah sulit menjangkaunya. Meskipun kelembagaan sosial sudah dibentuk bertahun-tahun lamanya, pembinaan yang dijalankanpun cenderung kelompok, yaitu pengurus dan anggota.

Permasalahan yang dihadapi para nelayan pada umumnya adalah lemah dalam hal permodalan. Akibatnya tingkat produksi rendah, inefisien skala usaha karena umumnya selalu terjerat dengan hutang, dan karena terdesak masalah keuangan posisi tawar ketika terjadi masa paceklik.

Pendekatan pembangunan melalui cara pandang kemandirian lokal mengisyaratkan bahwa semua tahapan dalam proses pemberdayaan harus dilakukan secara desentralisasi. Upaya pemberdayaan yang berbasis pada pendekatan desentralisasi akan menumbuhkan kondisi otonom, dimana setiap komponen akan tetap eksis dengan berbagai keragaman (diversity) yang dikandungnya.

Pengembangan kelembagaan sosial nelayan selama ini salah satunya akibat mengembangkan kelembagaan lokal yang hidup di pesisir pantai, karena dianggap memiliki jiwa ekonomi yang memadai. Ciri kelembagaan pada masyarakat tradisional adalah dimana aktivitas ekonomi melekat pada kelembagaan kekerabatan dan komunitas. Pemenuhan ekonomi merupakan tanggungjawab kelompok- kelompok komunal genealogis. Ciri utama kelembagaan tradisional adalah sedikit kelembagaan, namun banyak fungsi. Beda halnya dengan pada masyarakat modern yang dicirikan oleh munculnya banyak kelembagaan dengan fungsi-fungsi yang spesifik dan sempit-sempit.

Kemandirian lokal menunjukkan bahwa pembangunan lebih tepat bila dilihat sebagai proses adaptasi-kreatif suatu tatanan masyarakat dari pada sebagai serangkaian upaya mekanistis yang mengacu pada satu rencana yang disusun secara sistematis. Kemandirian lokal juga menegaskan bahwa organisasi seharusnya dikelola dengan lebih mengedepankan partisipasi dan dialog dibandingkan semangat pengendalian yang ketat sebagaimana dipraktekkan selama ini.

\subsection{Gambaran Nelayan di Nagari Tiku Selatan}

elompok-kelompok nelayan yang
dibentuk terbagi ke dalam 5
pengelompokkan kelembagaan,
yaitu kelompok penangkapan ikan, 
pengolahan ikan, budidaya ikan lele, kelompok usaha bersama dan kelompok pengawas masyarakat.

Berdasarkan klasifikasi Masyuri dalam Lucky Zamzami (2009:39) bahwa ciri-ciri nelayan buruh atau dikatakan nelayan tradisional ditandai dengan (a) kegiatan mereka yang lebih banyak menggunakan padat, kalaupun menggunakan mesin, ukuran atau tenaga mesin relatif kecil atau motor tempel dengan menggunakan alat tangkap yang sederhana; (b) teknologi yang dipakai untuk penangkapan atau pengolahan ikan yang masih sederhana dan (c) tingkat pendidikan dan keterampilan yang rendah. Ciri- ciri tersebut diatas dibuktikan dengan peralatan penangkapan ikan yang sederhana seperti perahu (biduak) yang memakai mesin tempel, alat pancing/jala sehingga hasilnya sangat berbeda jauh dengan peralatan nelayan modern.

Keterbatasan potensi serta modal usaha nelayan di Nagari Tiku Selatan yang memiliki pengertian nelayan yang bekerja dengan alat tangkap milik orang lain. Mereka harus membagi hasil tangkapannya dengan nelayan juragan (yang memiliki peralatan) sampai 65\% dengan pembagian 50\% untuk nelayan juragan dan $15 \%$ untuk mengatasi kerusakan.

Aktivitas penangkapan ikan yang dilakukan oleh nelayan Nagari Tiku Selatan hampir sama dengan aktivitas penangkapan ikan lainnya di berbagai daerah di wilayah pantai Barat Sumatera. Aktivitas penangkapan ikan yang dilakukan oleh nelayan buruh di wilayah pesisir pantai Selatan Sumatera Barat adalah membagan, memayang, memukat, menjaring dan memancing (Zamzami,2008,2009).

Salah satu faktor penting dalam aktivitas nelayan Nagari Tiku Selatan adalah menjual hasil penangkapan ikan. Hasil produksi berupa ikan yang telah ditangkap di laut oleh nelayan buruh merupakan produksi ikan yang cepat rusak sehingga harus segera dipasarkan. Kondisi ini menyebabkan para nelayan buruh menjual hasil tangkapannya secepatnya setelah berlabuh di tepi pantai. Biasanya hasil tangkapan para nelayan buruh akan langsung dijual di pinggir pantai, dimana di tempat tersebut telah menunggu para pedagang (toke') dan juga pengolah ikan untuk membeli hasil tangkapan mereka. Dalam proses penjualan ikan tersebut, nelayan buruh langsung berhubungan dengan para pedagang atau pengolah ikan tanpa ada perantara.

Harga ikan yang dijual oleh nelayan di Nagari Tiku Selatan bervariasi sesuai dengan jenis ikan yang ditangkap, yaitu:

a) Ikan Bulato (ikan Kembung) $1 \mathrm{~kg}$ seharga Rp. 13.000,-

b) Ikan Gabua $1 \mathrm{~kg}$ seharga Rp. 15.000,-

c) Ikan Kaliang-kaliang $1 \mathrm{~kg}$ seharga Rp. 7.000,-

d) Ikan Tongkol $1 \mathrm{~kg}$ seharga $\mathrm{Rp}$. 10.000,-

e) Ikan Tambolo $1 \mathrm{~kg}$ seharga $\mathrm{Rp}$. 14.000,-

f) Ikan Bowl putih $1 \mathrm{~kg}$ seharga Rp.40.000,-

g) Ikan Bowl hitam $1 \mathrm{~kg}$ seharga Rp.20.000,-

h) Ikan Tenggiri Aceh $1 \mathrm{~kg}$ seharga Rp. 20.000,-

Ada juga terdapat pengolahan bada teri (ikan teri), namun jarang karena ikan teri lumayan sulit di dapat.bUntuk aktivitas penangkapan ikan yang dilakukan oleh nelayan di Nagari Tiku Selatan terdapat beberapa perahu yang digunakan dalam mencari ikan, yaitu:

a) Kapal Bagan, kapal yang cukup besar menggunakan mesin sebagai penggerak kapal, dan memiliki lampu sebagai penarik ikan. Biasanya kapal bagan dapat ditemukan di daerah Suranti.

b) Kapal Tondo atau kapal boat, yaitu kapal dengan mesin disel seperti boat.

c) Pompong, kapal yang menggunakan tenda

d) Payang, yaitu biduak atau perahu bercadik.

e) Robin, yaitu perahu dengan menggunakan mesin robin atau mesin tempel seperti speedboat, biasanya hanya untuk 2 orang.

f) Sampan Boling yaitu sampan biasa dengan menggunakan dayung saja.

Untuk aktivitas penangkapan ikan di Nagari Tiku Selatan, terdapat hari di mana para nelayan buruh tidak diperbolehkan melaut, yaitu pada hari jum'at. Pada hari Jum'at tersebut para 
buruh nelayan hanya fokus beribadah (shalat Jum'at) terutama bagi yang lakilaki dimana kalau ada yang melanggar maka nelayan buruh yang melakukan akan mendapatkan sanksi sosial seperti cemoohan dari masyarakat. Kemudian saat ada kematian, buruh nelayan harus melayat ke rumah jenazah dan mengikuti proses- proses upacara kematian sebagai penghormatan kepada orang yang sudah meninggal.

Biasanya para nelayan Nagari Tiku Selatan ketika ke laut dilakukan pada pagi hari sekitar pukuln06.30 Wib, kemudian kembali pada pukul 16.00 Wib. Kegiatan tersebut dikatakan tidak menentu dimana tergantung kepada hasil tangkapan ikan. Untuk melakukan penangkapan ikan pada malam hari, tidak banyak dilakukan oleh para nelayan buruh dikarenakan kondisi fisik nelayan buruh dan penggunaan perahu sebatas payang dan perahu tanpa mesin.

\subsection{Gambaran Isteri-Isteri Nelayan Tiku}

$\mathrm{K}$ egiatan perempuan, utamanya isteri, di Nagari Tiku Selatan khususnya di Jorong Pasie Tiku, dalam bidang ekonomi banyak terkonsentrasi pada sektor informal. Mereka memiliki cara-cara atau terobosan-terobosan yang sangat berarti dalam membantu suami untuk menunjang kelangsungan ekonomi rumah tangga mereka. Istri juga dituntut untuk ikut berperan dalam mencari tambahan penghasilan untuk memenuhi kebutuhan keluarga, sehingga mereka tidak hanya tinggal diam di rumah untuk menanti dan membelanjakan penghasilan suami mereka dari melaut, namun mereka juga ikut terlibat dalam kegiatan mencari nafkah.

Peran perempuan dalam nafkah rumah tangga dimulai ketika perahu mulai kembali dari melaut dan membawa hasil tangkapan. Pada saat itu, perempuan terlibat dalam penjualan hasil tangkapan. Di Nagari Tiku Selatan khususnya di Jorong Pasie Tiku, perempuan mempunyai peran yang berarti hingga terjualnya hasil tangkapan. Sebagian besar perempuan ini adalah istri dari nelayan yang melaut. Mereka mempunyai tanggung jawab untuk menjual hasil tangkapan di pasar maupun di Tempat Pendaratan lkan (TPI).

Pada waktu pendaratan, para perempuan yang sebagaian besar adalah istri nelayan akan menunggu perahu suaminya mendarat di tempat pendaratan. Mereka secara bersamasama akan membantu suami mereka untuk menurunkan hasil tangkapan kemudian membawanya ke tempat penjualan, sedangkan kaum laki-laki beristirahat untuk melepas lelah di warung-warung sekitar tempat pendaratan atau langsung pulang ke rumah.

Penjualan ikan ini dikoordinasi oleh istri pemilik perahu atau oleh orang kepercayaan pemilik perahu. Hasil tangkapan ini dijual pada pedagang. Pedagang yang dikenal dengan istilah toke ini sebagian besar adalah penduduknya sendiri. Mereka berjualan ikan, baik di pasar Tiku maupun pasar nagari lainnya, bahkan ada yang berjualan hingga pasar kabupaten. Peran perempuan dalam pemasaran hasil tangkapan tidak memberikan kontribusi pendapatan secara langsung dalam nafkah rumah tangga. Di sini, mereka hanya berperan membantu memasarkan hasil tangkapan dan tidak mengambil keuntungan dari kegiatan tersebut, seluruh hasil penjualan diserahkan pada istri pemilik perahu untuk kemudian dibagi sesuai dengan peran masingmasing dalam penangkapan ikan. Pemilik perahu mendapatkan bagian sebanyak $60 \%$ sedangkan sisanya dibagi rata kepada seluruh awak perahu. Suatu hal yang berbeda jika perempuan berperan sebagai pedagang ikan. Sebagai pedagang, mereka mendapatkan keuntungan dari selisih harga penjualan dan pembelian. Rata-rata pendapatan yang diterima oleh pedagang ikan berkisar antara Rp. 10.000,00 hingga Rp. 50.000,00 setiap harinya. Besarnya pendapatan ini sangat tergantung pada besarnya modal yang mereka kelola. Semakin besar modal yang dimiliki, mereka dapat membeli ikan dalam jumlah banyak dan memasarkannya hingga ke pasar desa lain atau bahkan pasar kabupaten.

Di Nagari Tiku Selatan khususnya di Jorong Pasie Tiku, selain dijual langsung ke konsumen dalam bentuk segar, beberapa bakul merangkap sebagai pembuat pindang. Pindang adalah salah satu bentuk pengolahan sekaligus pengawetan ikan dengan cara memasak ikan pada suatu tungku yang terbuat dari tanah liat Pemindangan dilakukan sebagai upaya meningkatkan nilai jual ikan dan juga menjaga keawetan ikan, sehingga 
mengurangi risiko kerugian apabila ikan tidak segera laku terjual. Hasil pemindangan kemudian dijual kepada beberapa pedagang, baik yang berjualan di pasar maupun pedagang keliling. Nagari Tiku Selatan khususnya di Jorong Pasie Tiku, kegiatan produktif perempuan nelayan yang lain adalah sebagai pembuat pembuat jajanan rakik maco sejenis keripik pedas gurih dari tepung beras yang dibubuhi ikan laut kecil dan tipis dibagian atasnya (toping). Rata-rata dalam sehari, mereka dapat membuat jajanan sebanyak $5-10 \mathrm{~kg}$. Pekerjaan ini dapat diselesaikan dalam waktu kurang dari setengah hari.

Di Jorong Pasie Tiku, juga dijumpai kegiatan pengasinan ikan. Beberapa jenis ikan yang mempunyai nilai ekonomi rendah diolah menjadi ikan asin. Tujuan kegiatan ini adalah untuk mengawetkan ikan dan juga meningkatkan nilai ekonominya. Ikan segar dibersihkan kemudian dibelah, dilumuri garam, dan dijemur di bawah sinar matahari. Sepanjang jalan, banyak dijumpai papan kayu memanjang tempat penjemuran ikan. Selain istri, kegiatan ini seringkali melibatkan anak perempuan, utamanya untuk membantu menunggu dagangan ikan di pasar atau mengolah ikan untuk dibuat pindang.

Anak-anak perempuan ini mengisi waktu luangnya setelah pulang sekolah dengan bermain dan membantu orangtua mereka. Pada perempuan yang telah menginjak remaja, tanggung jawab yang diberikan oleh orang tua menjadi semakin besar. Mereka membantu menyelesaikan pekerjaan rumah sehari-hari seperti memasak, berbelanja, membersihkan rumah, mencuci pakaian, hingga mengasuh adik. Selain itu, mereka juga terlibat dalam kegiatan produktif seperti membersihkan ikan, mengupas udang, atau sekedar menunggu dagangan di pasar. Munculnya usaha kecil di pedesaan membawa dampak pada semakin meningkatnya peran perempuan dalam nafkah rumah tangga. Sumbangan perempuan dalam nafkah rumah tangga mengalami peningkatan. Kegiatan perempuan tidak lagi terbatas pada kegiatan pemasaran hasil tangkapan, namun lebih jauh dari itu, mereka terlibat dalam pekerjaan pengolahan.

Pada masyarakat di jorong Pasie Tiku, bukan hal baru apabila perempuan (istri) terlibat dalam nafkah rumah tangganya. Keterlibatan istri dalam nafkah rumah tangg mendapat dukungan dari para suami, sebab disamping pekerjaan ini tidak mengganggu tugas ibu sebagai ibu rumah tangga, juga sebagai upaya istri untuk mendapatkan nafkah tambahan guna memenuhi kebutuhan hidup sehari-hari. Kajian tentang peran perempuan dalam nafkah rumah tangga, utamanya di pedesaan menunjukkan bahwa peranan perempuan dalam sistem nafkah rumah tangga cukup signifikan.

Kondisi ini menunjukkan bahwa peranan perempuan sebagai pelaku ekonomi tidak boleh diabaikan, bahkan diperlukan dukungan teknologi untuk menunjang peranan perempuan dalam kegiatan sosial dan ekonomi agar para perempuan dapat mengalokasikan waktunya lebih banyak pada kegiatan produktif tanpa meninggalkan peranannya pada kegiatan domestik. Berbagai studi di negara berkembang telah menunjukkan bahwa peran perempuan dalam ekonomi rumah tangga sangatlah besar. Bahwa perempuan mempunyai peran dalam aktivitas ekonomi rumah tangga. Pada usaha tani, perempuan memberikan sumbangan curahan waktu kerja yang hampir sama dengan laki-laki. Kontribusi dalam aspek aktivitas ekonomi ini tidak diimbangi dengan peran pada aspek kontrol atau pengambilan keputusan. Pengambilan keputusan dalam rumah tangga masih didominasi oleh laki-laki (suami).

Peran perempuan pedesaan relatif lebih tinggi dalam kegiatan pascapanen dan kegiatan pengelolaan ternak daripada kegiatan pertanian lainnya. Partisipasi mereka hampir nihil dalam hal kegiatan budidaya, sedangkan beberapa dari mereka berpartisipasi dalam kegiatan non-pertanian seperti pembuatan kerajinan tangan dan menjahit. Penelitian ini juga menunjukkan bahwa perempuan pada rumah tangga petani memberikan kontribusi pendapatan rumah tangga melalui berbagai aktivitas ekonomi. Temuan lainnya menunjukkan bahwa di sebagian besar kasus partisipasi perempuan dalam proses pengambilan keputusan mengenai berbagai urusan rumah tangga lebih rendah daripada laki-laki.

Peningkatan peran perempuan lebih disebabkan oleh kondisi sosial ekonomi rumah tangga. Kebutuhan rumah tangga menjadi salah satu faktor utama yang menyebabkan perempuan bekerja di luar rumah. Walaupun di sebagian besar negara berkembang, perempuan diposisikan lebih 
inferior dibandingkan laki-laki, namun pergeseran peran yang terjadi merupakan suatu kebutuhan. Nilai-nilai budaya yang ada di masyarakat, mau tidak mau, harus bisa berkompromi dengan peningkatan kebutuhan rumah tangga.

\subsection{Nilai Tradisi dalam Aktivitas Penangkapan Ikan}

$\mathrm{T}$ radisi yang mengacu pada adat atau kebiasaan yang turun temurun, atau peraturan yang dijalankan masyarakat disandingkan dengan stuktur masyarakat. Tradisi merupakan produk sosial dan hasil dari pertarungan sosial politik yang keberadaannya terkait dengan manusia. Tradisi merupakan segala sesuatu yang berupa adat, kepercayaan dan kebiasaan. Kemudian adat, kepercayaan dan kebiasaan itu menjadi ajaran-ajaran atau paham-paham yang turun temurun dari para pendahulu kepada generasi-generasi paska mereka berdasarkan dari mitos-mitos yang tercipta atas manifestasi kebiasaan yang menjadi rutinitas yang selalu dilakukan oleh klan-klan yang tergabung dalam suatu bangsa. Secara pasti, tradisi lahir bersama dengan kemunculan manusia dimuka bumi. Tradisi berevolusi menjadi budaya. Itulah sebab sehingga keduanya merupakan personifikasi. Budaya adalah cara hidup yang dipatuhi oleh anggota masyarakat atas dasar kesepakatan bersama. Kedua kata ini merupakan keseluruhan gagasan dan karya manusia, dalam perwujudan ide, nilai, norma, dan hukum, sehingga keduanya merupakan dwitunggal. Untuk meningkatkan hasil tangkapan nelayan, banyak cara dilakukan oleh masyarakat nelayan untuk melestarikan nilai-nilai tradisi yang telah ada. Pada nelayan Tiku, tradisi yang sampai saat ini masih dilakukan adalah tradisi membangun rumpon secara tradisional. Nelayan Tiku, Kecamatan Tanjung Mutiara, Kabupaten Agam, memanfaatkan daun pinang sebagai rumpon (rumah ikan). Nelayan Tiku juga telah membangun istana ikan di perairan Tiku meski jumlahnya dirasakan masih kurang. Para nelayan berinisiatif membangun sendiri rumpon, sesuai dengan kemampuan mereka. Rumpon tradisional itu biasanya diletakkan tidak jauh dari garis pantai. Secara tradisional, ternyata mampu membantu meningkatkan jumlah ikan di sekitarnya. Namun rumpon tradisional tidak bertahan lama.

Disamping tradisi diatas, tradisi Budaya penyembelihan ternak atau disebut juga dengan festival Babantai Nagari Tiku merupakan kegiatan rutinitas secara turun temurun dari masyarakat Tiku menjelang $\mathrm{H}$ 1 hari Raya Idul Fitri, dengan banyak penyembelihan setiap tahunnya berkisar 300 ekor ternak kerbau dan sapi. Tradisi ini menyediakan sapi dan kerbau untuk disembelih di Tiku termasuk hari raya Idul Adha mencapai 321 ekor. Berat rata-rata kisaran 200-500 kg, kisaran harga $\mathrm{Rp} 16$ juta sampai Rp 20 juta per ekor dengan harga sebesar Rp 120 ribu per kilogramnya.

Tradisi alek nagari Tiku yang sudah turun temurun di gelar sejak nenek moyang dengan pemotongan ternak mencapai seratusan ekor. Tradisi bertujuan untuk memerikan rasa syukur atas nikmat yang diberikan oleh Tuhan yang maha esa terutama atas nikmat melimpahnya ikan tangkapan pada masyarakat nelayan. Hal tersebut juga dilakukan agar tidak ada masyarakat yang tidak makan daging setiap tahunnya di hari Lebaran. Hal ini merupakan marwah yang secara turun temurun dari nenek moyang masyarakat Tiku dengan menyembelih hewan ternak sebanyak seribu ekor. Tradisi ini memiliki nilai positif, diantaranya memudahkan warga mendapatkan daging segar dengan mutu terjamin dan harga terjangkau serta suasana keramainya dapat menjalin rasa kebersamaan warga. Tradisi festival "Alek Babantai" ini dipertahankan oleh masyarakat nelayan Tiku karena sudah menjadi tradisi yang multifungsi, selain sangat bermanfaat untuk mencegah kehadiran daging gelondongan, juga sekaligus ajang pemersatu bagi masyarakat terutama antara anak kemenakan dengan mamak.

Tradisi lainnya yang saat ini masih dipertahankan oleh nelayan Tiku adalah tradisi Tolak Bala. Tradisi ini dilakukan pada saat kondisi laut tidak memungkinkan untuk melaut atau mencari ikan. Cuaca di laut selalu tidak menentu dan selalu diikuti oleh badai yang berlangsung lama, hingga beberapa bulan. Kondisi ini membuat para nelayan tidak bisa melaut dan otomatis sangat mempengaruhi kepada kondisi ekonomi rumah tangga nelayan. Dengan kondisi tersebut, untuk meminta 
pertolongan dari Tuhan yang maha esa, maka dilakukanlah upacara tolak bala dengan melakukan wirid pengajian dan sekaligus menyembelih 1 ekor sapi sebagai bahan sesajian untuk diberikan ke laut.

\subsection{Yasinan, Wirid Pengajian, Arisan: Kelembagaan Sosial yang Mengakar pada Masyarakat nelayan Tiku}

K elembagaan tradisional yang masih hidup di Nagari Tiku Selatan adalah kelompok sosial pengajian, arisan ibu-ibu dan yasinan, masih berjalan dengan baik. Partisipasi rumah tangga terhadap kelompok sosial juga sangat baik. Hampir seluruh ibu-ibu terlibat dalam kegiatan rutin kelompok tersebut. Pengajian dan yasinan dilaksanakan setiap minggu secara bergilir dari rumah ke rumah. Sedangkan arisan dilaksanakan setiap dua minggu.

Strategi sosial dilakukan dengan jalan memanfaatkan ikatan-ikatan sosial yang ada di perdesaan baik berupa lembaga kesejahteraan lokal, hubungan produksi hingga jejaring sosial berbasis kekerabatan atau pertemanan. Rasa percaya antar warga (trust) sangat tinggi. Rasa percaya antar warga yang tinggi ini menyebabkan pola hutang-piutang antar rumah tangga dapat berjalan dengan baik. Pentingnya kepercayaan pribadi dalam mempertahankan modal sosial. Hutang menjadi salah satu bentuk strategi nafkah bagi rumah tangga miskin. Untuk berhutang mereka memanfaatkan jejaring sosial yang ada, seperti ikatan kekerabatan, pertetanggaan atau pertemanan. Hutang digunakan untuk memenuhi kebutuhan hidup sehari-hari atau kebutuhan yang mendesak seperti ketika anggota rumah tangga ada yang sakit. Jarang sekali hutang digunakan untuk keperluan pembelian barang konsumtif.

Modal sosial merupakan salah satu andalan bagi rumah tangga miskin. Ikatan kekerabatan, pertetanggaan dan pertemanan yang kuat memberikan ruang yang cukup bagi rumah tangga miskin untuk mengakses modal sosial ini. Keterlibatan rumah tangga miskin dalam kelembagaan kesejahteraan lokal cukup tinggi. $\mathrm{Di}$ Nagari Tiku Selatan tidak ada diskriminasi peran dalam kehidupan sosial kemasyarakatan bagi rumah tangga miskin. Pola relasi yang cenderung egaliter menyebabkan rumah tangga miskin dapat dengan mudah mengakses berbagai bentuk kelembagaan lokal ini. Bagi rumah tangga miskin, modal sosial merupakan aset yang sangat penting karena melalui modal sosial mereka dapat mengakses berbagai bentuk modal yang lain.

Tingkat partisipasi masyarakat, utamanya ibu-ibu di dalam kelompok cenderung tinggi. Tingkat kepercayaan dan solidaritas antar warga cukup tinggi. Hal ini dibuktikan dengan bertahannya lembaga tradisional seperti gotong royong. Tingkat kepercayaan antar warga yang tinggi juga tampak dari hutang piutang antar warga yang berjalan dengan lancar. Kelompok sosial yang ada di Nagari Tiku Selatan beranggotakan masyarakat yang berasal dari dalam nagari. Akses terhadap sumber daya dan informasi dari luar masih terbatas. Modal sosial masih terbatas digunakan untuk pemenuhan kebutuhan jangka pendek (konsumtif), belum mengarah pada pemenuhan kebutuhan jangka panjang (produktif). Modal sosial belum dimanfaatkan untuk menunjang kegiatankegiatan produktif karena keterbatasan modal manusia dan modal finansial. Kegiatan kelompok yang terbatas pada dimensi sosial religius perlu dikembangkan ke arah ekonomi. Kegiatan produktif dapat dikembangkan secara bersama-sama oleh masyarakat. Tingkat kepercayaan antar warga yang tinggi sangat bermanfaat untuk memulai kegiatan simpan pinjam dan merintis usaha melalui modal bersama.

Dalam seluruh aktivitas yang berkaitan dengan arisan merupakan gejala umum yang dipraktikkan hampir oleh setiap penduduk nelayan di Nagari Tiku Selatan, di samping hutang atau kredit. Di Nagari Tiku Selatan terdapat tidak kurang dari 20-an kelompok arisan dengan jumlah perolehan arisan bisa mencapai jutaan bahkan puluhan juta. Keanggotaan para nelayan dalam kelompok arisan bisa lebih dari satu. Hasil uang yang diperoleh dari hasil arisan ini mereka sertakan lagi dalam kelompok kelompok arisan yang lain, sehingga yang bersangkutan bisa memperoleh modal untuk membuka usaha perdagangan kecil-kecilan (pedagang kelontong), membuat rumah, menyelenggarakan lamaran dan pesta perkawinan, naik haji, dan atau dibelikan perahu/jaring kecil untuk melanggengkan matapencaharian mereka sebagai nelayan. Hal ini, juga berlaku di kalangan para 
juragan pemilik kapal/perahu dengan jumlah omset arisan yang lebih besar (Rp.10 juta Rp.50 juta). Oleh karena itu, sejumlah juragan kapal/perahu tidak hanya memiliki lebih dari satu armada kapal/perahu besar yang berharga ratusan juta rupiah, tetapi mereka juga mampu mengembangkan bisnis lain seperti membuka toko, tetapi kebanyakan menginvestasikannya dengan membeli mobil-mobil penumpang (colt diesel) untuk usaha transportasi pengangkutan ikan olahan.

Hutang sebagai salah satu karakteristik perekonomian desa tradisional, dalam banyak hal hampir selalu tidak menguntungkan secara ekonomis bagi si penghutang atau peminjam (kreditur). Hal ini, tampaknya kurang disadari oleh masyarakat nelayan tradisional di Nagari Tiku Selatan, sehingga sampai kini pun masyarakat setempat masih banyak terlibat dalam praktik hutang dan kredit, selain menggabungkan diri ke dalam kelompokkelompok arisan yang menjamur di Nagari Tiku Selatan, sebagaimana telah dibicarakan di atas. Hutang atau kredit (ngredit) yang dilakukan oleh masyarakat nelayan setempat, umumnya tidak dalam kerangka hubungan kerja antara nelayan dan juragan. Hutang atau permintaan kredit biasanya dilakukan oleh para nelayan kepada orang-orang kaya tetanggatetangga mereka sendiri yang sama sekali tidak memiliki hubungan kerja dengan dirinya, akan tetapi, pada umumnya mereka lebih sering meminjam uang kepada kepala-kepala arisan yang banyak memegang uang-uang titipan para anggotanya.

\subsection{Perwujudan Tradisi dan Peran Kelembagaan Sosial Nelayan}

D alam rangka pemberdayaan masyarakat kelompok nelayan yang ada di Nagari Tiku Selatan untuk mencapai tujuan maka disusun suatu strategi kebijakan dengan harapan akan didapat suatu pemecahan dalam memberdayakan masyarakat nelayan secara maksimal sehingga berdampak pada menurunnya tingkat desa tertinggal dan menuju kemandirian desa secara ekonomi, di wilayah Nagari Tiku Selatan, khususnya nelayan. Ada empat komponen yang akan disusun sebagai strategi pengembangan kelembagaan kelompok nelayan yang sangat diharapkan untuk menunjang berdayanya lembaga kelompok nelayan yang ada di Nagari Tiku Selatan.

Untuk mencapai nelayan yang berkualitas, maka menjadi suatu keharusan bahwa kelompok nelayan yang ada harus memiliki gerak atau kekuatan yang dapat menentukan dan mempengaruhi perilaku kelompok dan anggota-anggotanya dalam mencapai tujuan-tujuan secara efektif. Dengan kata lain kelompok tersebut harus berfungsi efektif untuk kepentingan para anggotanya. Salah satu faktor penting untuk terwujudnya kelompok tani yang efektif adalah berjalannya kepemimpinan dari ketua kelompok nelayan tersebut. Ketua kelompok dapat dipandang sebagai agen primer untuk efektifnya kelompok, karena peran strategisnya dalam mempengaruhi atau menggerakkan anggota-anggota di kelompoknya untuk mencapai tujuan-tujuan kelompok maupun dari anggota-anggotanya. Ketua kelompok dengan kepemimpinannya yang tergolong baik atau sangat tinggi tersebut akan memberikan peluang yang sangat besar untuk tercapainya keefektifan di kelompok yang dipimpinnya tersebut. Hal ini dimungkinkan karena ketua kelompok yang kepemimpinan baik atau sangat tinggi memiliki kemampuan yang lebih baik atau lebih tinggi di dalam mempengaruhi anggota lainnya. Hal ini termasuk di dalam menyusun struktur atau pengubahan stuktur yang diselaraskan dengan persepsi dan harapan para anggota untuk mencapai keberhasilan usaha kelompok. Pada kelompok yang kepemimpinannya tergolong baik atau sangat tinggi, keberhasilan kelompok di dalam mencapai tujuannya, keadaan moral anggota kelompok dan tingkat kepuasan dari para anggota terbukti lebih baik atau lebih tinggi dibanding dengan kelompok yang kepemimpinannya belum berjalan dengan baik.

Pembinaan dari berbagai instansi hendaknya bersifat terintegrasi, lebih mengedepankan kepentingan nelayan, dalam arti nelayan bukan dijadikan obyek untuk kepentingan institusional yang sekedar administrasi keproyekan. Adanya koordinasi yang efektif antar kelembagaan pemerintah dalam pembinaan masyarakat nelayan dapat meningkatkan efisiensi dan produktivitas perikanan melalui kemitraan usaha. Peran pemerintah lebih ditonjolkan pada aspek mediasi, konsultasi, dan 
fasilitasi dalam membangun kemitraan pengolahan produksi ikan yang berdayasaing.

Dengan adanya tradisi-tradisi yang dilakukan oleh masyarakat nelayan Tiku, maka niai-nilai tradisi yang dihasilkan berupa perwujudan rasa solidaritas, saling menghargai, tolong menolong dan berusaha meningkatkan derajat ekonomi rumah tangga nelayan. Melalui beberapa tradisi yang dilaksanakan, kelembagaan sosial yang telah mengakar dalam masyarakat nelayan Tiku seperti kelompok sosial pengajian, arisan ibu-ibu dan yasinan memiliki peran untuk melaksanakan perwujudan-perwujudan tersebut.

Kelembagaan sosial yang ada terwujud dalam tradisi religi yang mampu mempererat ikatan kekerabatan yang ada pada masyarakat nelayan Tiku. Mereka secara bersama-sama mengalokasikan waktu dan pikirannya untuk peningkatan ekonomi dan sosial di kalangan mereka. Apabila terjadi sesuatu kepada salah satu rumah tangga nelayan, maka kelembagaan sosial yang ada membantu kesulitan anggotanya. Terkait erat dengan kondisi laut yang tidak menentu, maka peran kelambagaan sosial juga membantu kesulitan pada nelayan dan biasanya mereka akan dibantu dengan sistem simpan pinjam. Hal ini sudah berlangsung secara tradisi dalam kehidupan masyarakat nelayan Tiku.

\section{F. Kesimpulan}

$\mathrm{K}$ elembagaan sosial atau pranata sosial mampu memberikan kekuatan yang positif bagi nelayandalam kehidupan keseharian mereka. Kelembagaan sosial perikanan dalam hal ini mampu memberikan jawaban atas permasalahan di atas. Penguatan kelompok sosial nelayan melalui kelembagaan sosial merupakan suatu kebutuhan yang sangat mendesak dan mutlak diperlukan oleh nelayan, agar mereka dapat bersaing dalam melaksanakan kegiatan usaha perikanan dan dapat meningkatkan kesejahteraan hidupnya. Kelembagaan sosial mempunyai peran yang penting dalam melestarikan tradisi-tradisi yang telah terbentuk sejak lama. Tradisi yang turun temurun mampu meningkatkan pengembangan masyarakat nelayan terutama kepada aspek kekerabatan dan ikatan emosional sesama nelayan. Tradisi tersebut berupa tradisi pembuatan

\begin{tabular}{llr}
\multicolumn{2}{c}{ Pengembangan masyarakat } \\
nelayan melalui kelembagaan sosial \\
perikanan merupakan suatu upaya
\end{tabular} perikanan merupakan suatu upaya
pemberdayaan terencana yang dilakukan secara sadar dan sungguh-sungguh melalui usaha bersama nelayan untuk memperbaiki keragaman sistem perekonomian masyarakat pedesaan. Arah pemberdayaan nelayan akan disesuaikan dengan kesepakatan yang telah dirumuskan bersama. Dengan partisipasi yang tinggi terhadap kelembagaan nelayan, diharapkan rasa ikut memiliki dari masyarakat atas semua kegiatan yang dilaksanakan akan juga tinggi. Keberhasilan penerapan suatu kelembagaan sosial nelayan tidak sematamata diukur dengan nilai tambah ekonomi, namun harus mempertimbangkan peran dan fungsi nilai-nilai sosio-kultural secara utuh.

Kelembagaan tradisional yang masih hidup di Nagari Tiku Selatan adalah kelompok sosial pengajian, arisan ibu-ibu dan yasinan, masih berjalan dengan baik. Partisipasi rumah tangga terhadap kelompok sosial juga sangat baik. Hampir seluruh ibu-ibu terlibat dalam kegiatan rutin kelompok tersebut. Pengajian dan yasinan dilaksanakan setiap minggu secara bergilir dari rumah ke rumah. Sedangkan arisan dilaksanakan setiap dua minggu. Strategi sosial dilakukan dengan jalan memanfaatkan ikatan-ikatan sosial yang ada di perdesaan baik berupa lembaga kesejahteraan lokal, hubungan produksi hingga jejaring sosial berbasis kekerabatan atau pertemanan.

Melalui peran kelembagaan sosial dianggap mampu melestarikan tradisi-tradisi yang sejak lama dilakukan di nelayan Tiku. Mereka menjalankan kegiatan tradisi yang didukung dengan aktivitas untuk mempererat tali silaturahmi dan membantu diantara mereka. Apabila salah satu anggota rumah tangga mengalama kesulitan maka dia akan dibantu melalui peran kelembagaan sosial tersebut. 


\section{Daftar Pustaka}

Acheson, James M. (1981). "Anthropology of Fishing". Annual Review Anthropology Inc. Vol. 10. P

$$
\text { 275-316 }
$$

Astuty, Ernany Dwi dkk. 2006. Restrukturisasi Institusi Ekonomi. Jakarta, Pusat Penelitian Ekonomi- LIPI.

Arief, A. Adri. "Pemberdayaan Nelayan Melalui Pendekatan Kelembagaan Lokal (Studi Kasus Desa Pajukukang, Kecamatan Maros Utara, Kabupaten Maros" dalam http://id.scribd.com/doc/13134563/Dr-AndiAdri-Arief-kelembagaan-masyarakat-pesisir, diakses tanggal 25 Januari 2013, jam 22.50 .

Boedhisantoso, S.(1999). Komunitas Lokal di Kawasan Pesisir dan Pemberdayaannya. Makalah

Lokakarya Pembangunan Pranata Sosial Komunitas pesisir. Depok $30 \mathrm{Mei}-1$ juni 1999

Bungin, Burhan, 2004, Metodologi Penelitian Kualitatif:Aktualisasi Metodologis ke Arah Ragam Varian Kontemporer, Jakarta: PT. RajaGrafindo Persada.

Cohen, A. P. 1985. The Symbolic Construction of Community London: Tavistock

Danim, Sudarwan, 2002, Menjadi Peneliti Kualitatif, Bandung: Pustaka Setia.

Frazer, E. 1999. The Problem of Communitarian Politics: Unity and Conflict. Oxford: Oxford University

$$
\text { Press. }
$$

Ginkel, Rob van. 2007. Coastal Cultures: An Anthropology of Fishing and Whaling Traditions.

$$
\text { Apeldoorn: Het Spinhuis Publishers }
$$

Kamus Besar Bahasa Indonesia: Tim Penyusun Kamus Besar Bahasa, (Ed-3. Cet-1 Jakarta ; Balai

$$
\text { Pustaka } 2001 .
$$

Keesing, Roger M. 1989. Antropologi Budaya: Suatu Perspektif Kontemporer. Jakarta:

Erlangga

Kharisma Nugroho dan Kwan Men Yon, 2011. Pengurangan Resiko Bencana Berbasis Komunitas di Indonesia dalam http://www.mpbi.org/files/workshops/ 20111205-Kharisma-N-Kwan-MY_PRBBK-di-Indonesia_Nov-2011.pdf

Kluckhon, Clyde 1984. "Cermin bagi Manusia", dalam Parsudi Suparlan (Ed.). Manusia,Kebudayaan, dan Lingkungannya. Jakarta: Rajawali Pers.

Koentjaraningrat. 1987. Kebudayaan Mentalitas dan Pembangunan. Jakarta: PT Gramedia Kusnadi. 2000. Nelayan: Strategi Adaptasi dan Jaringan Sosial. Bandung: Humaniora Utama Press. Perekonomian

2001. Pangamba' Kaum Perempuan Fenomenal: Pelopor dan Penggerak Masyarakat Nelayan. Bandung: Humaniora Utama Press. 2003. Akar Kemiskinan Nelayan. Yogyakarta: LKiS.

Media. 2009. Keberdayaan Nelayan dan Dinamika Ekonomi Pesisir. Yogyakarta: Ar- Ruzz

.2010. "Kebudayaan Masyarakat Nelayan" dalam Makalah ini disampaikan dalam kegiatan JELAJAH BUDAYA TAHUN 2010, dengan tema "Ekspresi Budaya Masyarakat Nelayan di Pantai Utara Jawa", yang Diselenggarakan oleh Balai Pelestarian Sejarah dan Nilai Tradisional, Kementeian Kebudayaan dan Pariwisata, di Yogyakarta, tanggal 12-15 Juli 2010.

Lassa dan dkk. 2009. Pengelolaan Risiko Bencana Berbasis Komunitas (PRBBK). Jakarta: Penerbit PT Gramedia Widiasarana Indonesia

Masyhuri. 1995. Pasang Surut Usaha Perikanan Laut, Tinjauan Sosial Ekonomi Kenelayanan di Jawa dan Madura 1850-1940. Vrije Universiteit Academich Proefschrijft.

Moleong, Lexy, 2001, Metode Penelitian Kualitatif, Bandung: PT.Remaja Rosda Karya. 
Neuman, W. Lawrence, 2006, Social Research Methods: Qualitative and Quantitative Approaches $6^{\text {th }}$

Edition, US: Pearson International Edition

Pasaribu LO. 2007. "Kelembagaan Pengelolaan pada Masyarakat Dayak Kenyah di Pampang Kecamatan Samarinda Utara, Kalimantan Timur" [skripsi]. Bogor: Fakultas Kehutanan, Institut Pertanian Bogor

Pranadji T. 2003. Menuju Transformasi Kelembagaan dalam Pembangunan Pertanian dan Pedesaan.

Jakarta: Pusat Penelitian dan Pengembangan Sosial Ekonomi Pertanian.

Rudito, Bambang dan Melia Famiola, 2008, Social Mapping (Metode Pemetaan

Sosial): Teknik

Memahami Suatu Masyarakat atau Komuniti, Bandung: Rekayasa Sains.

Sallatang, Mohammad Arifin. 1982. "Pinggawa Sawi Suatu Studi Sosiologi Kelompok Kecil". Disertasi.

Makassar: Universitas Hasanuddin.

Soekanto S. 2002. Sosiologi Suatu Pengantar. Jakarta: PT. Raja Grafindo Persada

Soemardjan S, Soelaeman S. 1974. Setangkai Bunga Sosiologi. Jakarta: Fakultas

Ekonomi. Universitas Indonesia.

Zamzami, Lucky. (2009). "Sistem Pengetahuan Lokal Nelayan Terhadap Teknologi Penangkapan Ikan pada Masyarakat Pasar Laban, Kecamatan Bungus Teluk Kabung, Kota Padang" dalam Jurnal FENOMENA Volume 07, Nomor 02, September 2009

Zamzami, Lucky. (2009). "Studi Kualitatif Dampak Perubahan Sosial terhadap Amalan Merantau di Kalangan Nelayan." Satu Kajian Kes di Kelurahan Purus, Kota Padang: UKM Malaysia: Tesis yang tidak dipublikasikan.

Zamzami, Lucky. 2010. Pemberdayaan Ekonomi Masyarakat Pesisir di Nagari Ampiang

Perak, Sumatera

Barat dalam Jurnal MIMBAR MIMBAR, Vol. XXVII, No. 1 (Juni 2011): 113-125

Terakreditasi' SK Dikti No. 64a/DIKTI/Kep/2010 